Article

\title{
Investigation of Kenaf Paper in the Presence of PVA for Transformers Application
}

\author{
Muhammad Umair ${ }^{1, *}$, Norhafiz Azis ${ }^{1,2, *}$, Rasmina Halis ${ }^{3}$ and Jasronita Jasni ${ }^{1}$ \\ 1 Advanced Lightning, Power and Energy Research Centre (ALPER), Department of Electrical and Electronic \\ Engineering, Universiti Putra Malaysia, Serdang 43400, Selangor, Malaysia; jas@upm.edu.my \\ 2 Institute of Advanced Technology (ITMA), Universiti Putra Malaysia, Serdang 43400, Selangor, Malaysia \\ 3 Department of Natural Resource Industry, Faculty of Forestry and Environment, Universiti Putra Malaysia, \\ Serdang 43400, Selangor, Malaysia; rasmina@upm.edu.my \\ * Correspondence: gs46108@student.upm.edu.my or umair9926@gmail.com (M.U.); \\ norhafiz@upm.edu.my (N.A.)
}

Received: 30 September 2020; Accepted: 20 October 2020; Published: 6 November 2020

\begin{abstract}
This paper presents an investigation on the physio-mechanical properties and AC breakdown voltage of the Kenaf paper in the presence of Polyvinyl Alcohol (PVA) for transformers application. Kenaf bast fibers were used in order to produce the paper through the soda pulping process. The pulps were subjected to beating up to 12,000 revolutions, whereby the PVA was added to the pulps at a different weight percentage concentration up to $12 \%$. Morphological study was carried out on the Kenaf paper based on Scanning Electron Microscopy (SEM). The apparent density, Tensile Index (TI), Burst Index (BI), Tear Index (TeI), and AC breakdown voltage of the Kenaf paper were measured. It is found that the TI and BI of Kenaf paper can be slightly improved through the introduction of PVA. On other hand, the TeI of the Kenaf paper decreases with the increment of the PVA. The AC breakdown voltage of the Kenaf paper slightly increases with the increment of PVA weight percentage concentration.
\end{abstract}

Keywords: kenaf fiber; insulation paper; polyvinyl alcohol; physio-mechanical; AC breakdown test; beating

\section{Introduction}

Wood based insulation papers have been used for decades as insulating materials in transformers, owing to its good physio-mechanical and electrical properties [1,2]. Even though it is sustainable, it can be subjected to shortages under extreme deforestation [1-3]. Recently, significant efforts have been carried out in order to explore the viability of non-wood fibers application as electrical insulation. Currently, non-wood fibers have been used in the pulp and paper industries. Although the non-wood based papers are inferior to wood based papers, several treatments can improve its characteristics $[3,4]$. Several non-wood plants have been used for papermaking, such as bamboo, Kenaf, baggase, jute, and cotton [4].

Kraft and soda processes are among the approaches used for pulping the non-wood plants. The soda process is mostly preferred for the pulping non-wood fibers, since it only requires Sodium Hydroxide $(\mathrm{NaOH})$ and the production time is shorter than Kraft process [5]. Soda process could produce high yields, without affecting the overall quality of the end products $[5,6]$. This process results in pulps with high insoluble carbohydrates. It is also found that the strength and lignin contents of pulps that are made from soda process are almost identical with Kraft process [5-7].

Cellulose is known as the principal component for both non-wood and wood fibers [8]. The lengths of wood fibers are slightly longer than non-wood fibers [8,9]. The chemical compositions and morphological 
characteristics, such as fibers width and length, determine the paper quality. The average fiber length of non-wood plants is between $0.6 \mathrm{~mm}$ and $30 \mathrm{~mm}$ [10]. Lumen size and thickness of the cell wall affect the rigidity and strength of non-wood fiber papers $[4,10]$. Fibers with large lumens and thin walls could be flattened once subjected to pulping. This process increases the contacts among the fibers and lead the increment of the strengths. Nowadays, the papermaking that is based on the non-wood fibers has attracted demands in wide range of applications [9]. Previously, the use of non-wood fibers is mainly for writing papers, but, in recent years, its applications have expanded in other areas, such as tissue, printing papers, and corrugated boards [7-9].

Non-wood fibers such as cotton, manila, hemp and flax have also been used for insulation applications, such as cables and telephones [11-14]. These fibers have good strength, low cost, good elasticity, and flexibility properties. In addition, it can comply with the size requirements and manufacturing processes [12]. Cotton fibers have been used in transformer insulation, but it has limited thermal capacity and high moisture absorption [14]. Flax fibers have been used as insulation in the capacitor [11-14]. The combination of wood fibers and manila hemp fibers has also been used for telephone insulation [11-14]. Currently, there are limited studies that have been carried out in order to examine the suitability of Kenaf fibers as an alternative electrical insulation for transformers.

Kenaf is one of the non-wood plants that have been used in twine, coarse cloth, rope, animal bedding, packaging, and paper industries. Kenaf fibers have also been utilized for writing papers and newsprints due to its high strength characteristics of fibers [15-18]. Kenaf plants consist of core and bast fibers that are short and long, respectively [16,18]. Bast fibers are longer than core fibers ranging from $1.15 \mathrm{~mm}$ to $4.03 \mathrm{~mm}$ [18]. Long fibers are one of the main requirements for the transformer's insulation since it needs to withstand the possible mechanical movements and heat while in-service [8,11-14]. The width of Kenaf fibers is between $13.8 \mu \mathrm{m}$ and $30 \mu \mathrm{m}$ and it is dependent upon the age, position, and species [10,18].

Non-wood paper production is basically a two-step process whereby the fibrous raw materials are first processed into pulps [19]. Pulping is carried out in order to separate fibers from dust and other unwanted chemicals [19]. The beating and refining of fibers are carried out to form thin fiber slurry that is suspended in solution [20]. The fiber network is built on a thin screen and it is pressed to maximize density [21]. The fiber network is further dried to extract residual moisture [22]. The beating process increases the bonding between fibers by fibrillation, thus increases the fiber surface contact area [20-25].

The performance of the paper can be improved through the introduction of chemical additives. There are two types of additives known as functional and process chemicals. The functional chemicals increase the paper properties directly while the process chemicals influence operations on or near paper machines [25-27]. Process chemicals are retention aids, biocides, dispersants, and defoamers [26-29]. Functional chemicals, such as fillers, sizing agents, dyes, optical brighteners, and wet/dry additives can be used in order to enhance or modify the specific characteristics of the papers [28]. It can be introduced internally or layered on the surface of the sheet [28]. Hydrogen bonds and friction forces between fibers are the main forces that determine the strength of fiber interactions in the papers whereby it can be improved by the functional chemicals [29-32].

Polyvinyl Alcohol (PVA) is one of the water-soluble synthetic polymers that has been used as functional chemical additives in papermaking $[29,30]$. To remove the acetate groups, PVA is subjected to partial or complete polyvinyl acetate hydrolysis, while other vinyl polymers are formed by the polymerization of its individual monomers [29-32]. PVA has been widely used in several applications, such as textiles, paper, fiber, ceramics, and wood [29,31]. PVA could enhance the paper resistance to oils and fats [29]. It has also been used with biopolymers and other hydrophilic polymers with the purpose of increasing paper's mechanical properties due to its structural compatibility and hydrophilic characteristics [29-32].

In this paper, Kenaf paper for electrical insulation purpose has been developed and fabricated. The Kenaf pulps are prepared and subjected to beating up to 12,000 revolutions. PVA has been introduced in the Kenaf pulps in order to further improve its physio-mechanical properties and AC 
breakdown voltage. Tensile Index (TI), Burst Index (BI), Tear Index (TeI), thickness, apparent density, and AC breakdown voltage of the Kenaf paper are measured and analyzed. The main contribution of the study is regarding the development of the Kenaf paper with PVA as the enhancement material for application in transformers. The findings of the results can be the basis for further improvement of Kenaf paper for purpose of electrical insulation.

\section{Preparation of Kenaf Paper}

Figure 1 illustrates the process of producing the Kenaf insulation papers. The raw material for the pulping was Kenaf bast fibers and it was obtained locally. In order to prepare Kenaf fibers for pulping, fiber threads were screened and thoroughly cleaned from dust and grime [33]. The threads were cut into $10 \mathrm{~cm}$ of length to make a total of $1 \mathrm{~kg}$ of fibers based on the Oven Dry (OD) method. Next, the pulping for Kenaf bast fibers was carried out based on the soda pulping method. Beating process was performed on the Kenaf bast fiber pulps. The speed of the beating was set at 3000 revolutions step and it was increased up to 12,000 revolutions [33]. The chemical treatment was performed by wet-end, whereby PVA was added with weight percentage concentration ranging from $3 \%$ to $12 \%$. Wet-end is a phase of papermaking process where the pulp is in slurry form (mixture of fiber and water). Finally, the handsheets were prepared for the physio-mechanical and electrical tests.

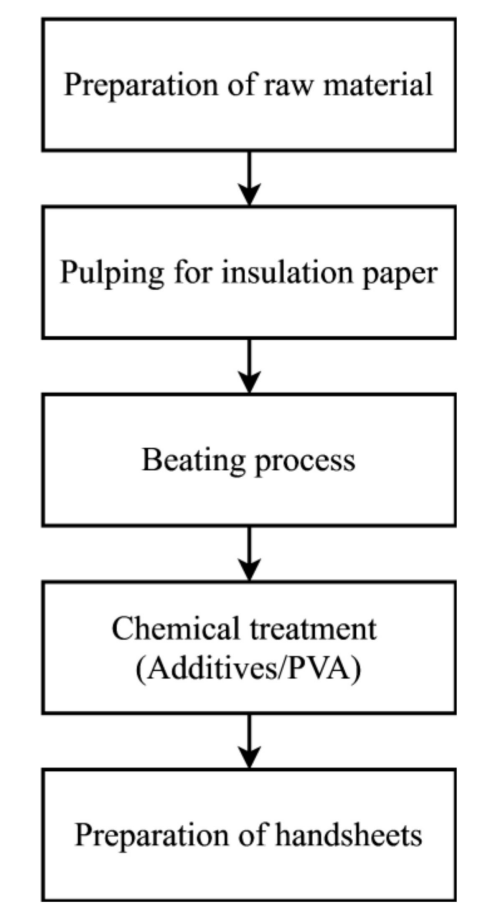

Figure 1. The process to produce Kenaf insulation paper.

\subsection{Pulping Process}

The Kenaf fibers were treated by soda pulping process through a rotary digester. For the pulping parameters, the concentration of $\mathrm{NaOH}$ was set to $14 \%$ with liquor to wood ratio of $7: 1$, respectively. The initial temperature of the pulping was set at $35^{\circ} \mathrm{C}$ with a pressure of $140 \mathrm{psi}$. It took $90 \mathrm{~min}$. to reach $170{ }^{\circ} \mathrm{C}$ whereby it was maintained for $30 \mathrm{~min}$. [33].

Figure 2 shows the soda pulping process of the Kenaf fibers for insulation papers. The Kenaf fibers, together with $\mathrm{NaOH}$ and distilled water, were fed into the digester for cooking based on the pulping parameters. After the process black liquor has been produced as by-products whereby the pulp was extracted and further cleaned with water. Black liquor mainly consists of lignin, hemicellulose and other extractives from the fibers after pulping, leaving behind mostly cellulose. After the separation 
of black liquor from fibers, the pulps still contained coarse fibers, dust, bark, and digester brick, which were removed by the screening process. A centrifugal separator was used to remove the excess water from the pulp. Next, the pulp was stored in a chiller at $6{ }^{\circ} \mathrm{C}$. The percentage of yield for the pulping was $59.17 \%$, and it was determined based on Equation (1).

$$
\text { Yield }(\%)=\frac{\text { OD weight of pulp }(g)}{\text { OD weight of raw material }(g)} \times 100
$$

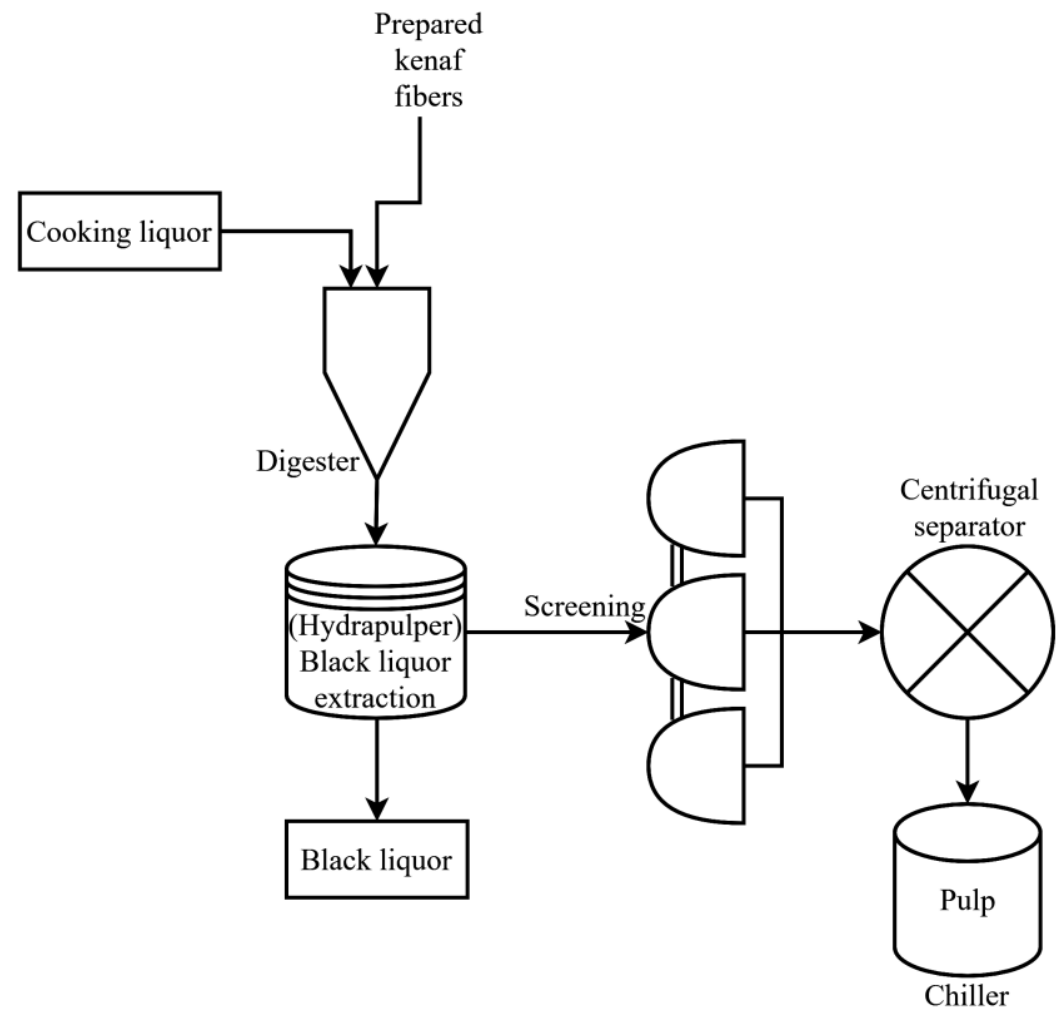

Figure 2. Pulping process of Kenaf fibers.

\subsection{Freeness of Pulp}

The pulp freeness was measured in order to determine the level of drainage for a condensed pulp suspension as well as to examine the surface conditions and swelling of the Kenaf fibers. The pulp's freeness was measured according to TAPPI T227 [34]. A freeness tester, which consisted of a drainage chamber and measuring funnel was used to measure the pulp freeness, as shown in Figure 3. The tester was first thoroughly washed with distilled water. Drainage chamber was placed on the upper support bracket with its lower lid closed and both upper lid and air-cock opened. The graduate cylinder was placed in positions to receive the discharged from the side orifice and a container to collect the discharge from the bottom orifice. Next, $1 \mathrm{~L}$ of suspended pulp was taken from a stock divider and then poured into the chamber. The top of the lid and air cock were closed and, subsequently, the bottom lid was opened, which discharged the pulp suspension through the side orifice. The volume that was discharged from the side orifice was recorded in millimeter, which represented the freeness of pulp. 


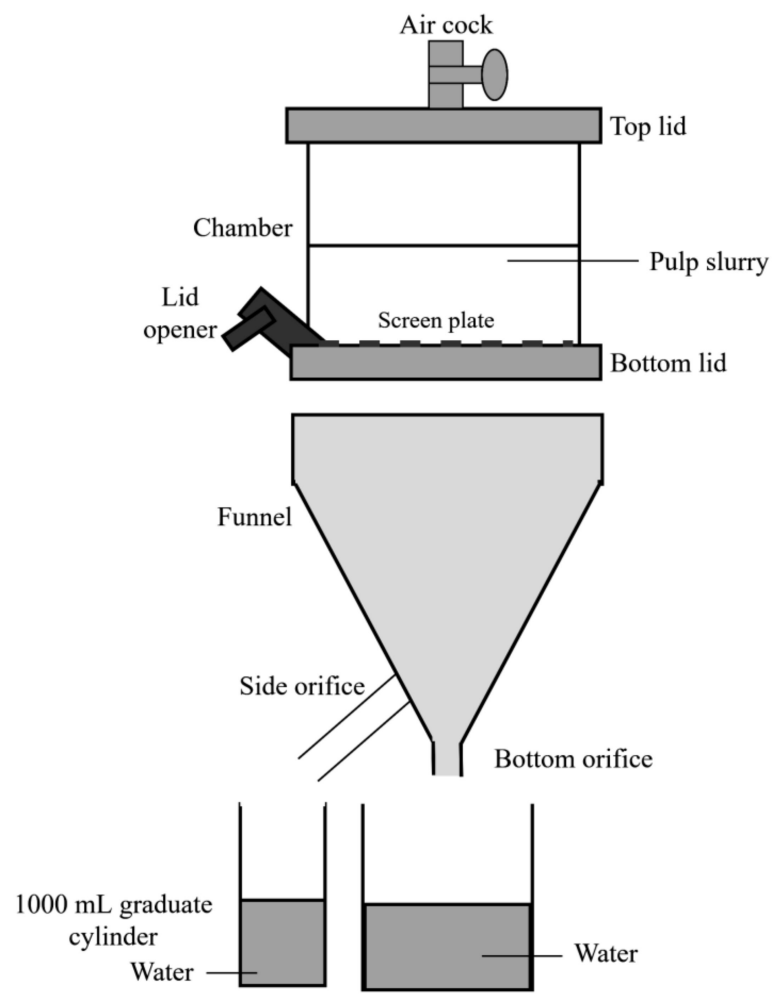

Figure 3. Pulp freeness measurement.

\subsection{Classification of Kenaf Fibers}

Baur MC Nett fiber classifier was used to determine the characteristics of Kenaf fibers while using Kenaf pulp as per TAPPI T233 [35]. In total, $10 \mathrm{~g}$ OD pulp was added in $2 \mathrm{~L}$ of water for $4 \mathrm{~h}$. Next, a mixer was used to disintegrate the solution in order to produce homogenous pulp suspension, as shown in Figure 4. The pulp suspension was subjected to a fiber classifier fitted with 4 meshes that consisted of filter papers. The long fibers in the pulp suspension maintained on the first mesh, while the short fibers remained on the final mesh. The lengths of fibers were measured by a Nikon profile projector V12 after drying the filter paper for $24 \mathrm{~h}$ at room temperature.

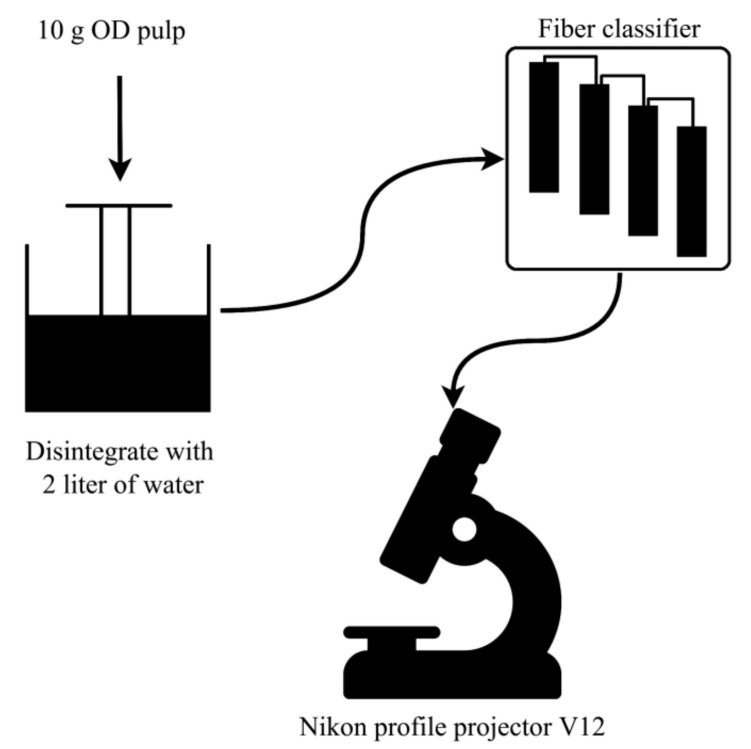

Figure 4. Classification of Kenaf fibers. 


\subsection{Beating Process}

The pulps were subjected to the beating procedures by Noram PFI mill in accordance with TAPPI T248 [36]. $24 \mathrm{~g}$ OD pulp was diluted with $2 \mathrm{~L}$ of distilled water and it was disintegrated at 50,000 revolutions. First, the pulp consistency, C, was set to $10 \%$ based on Equation (2) before the beating was performed [36]. The beating interval was set at 3000 revolutions and it was increased to 12,000 revolutions, as shown in Figure 5.

$$
C=\frac{O D P}{W P} \times 100
$$

where,

$C=$ consistency of pulp $(\%)$

$O D P=$ oven dry weight of pulp $(\mathrm{g})$

$W P=$ weight of pulp $(\mathrm{g})$

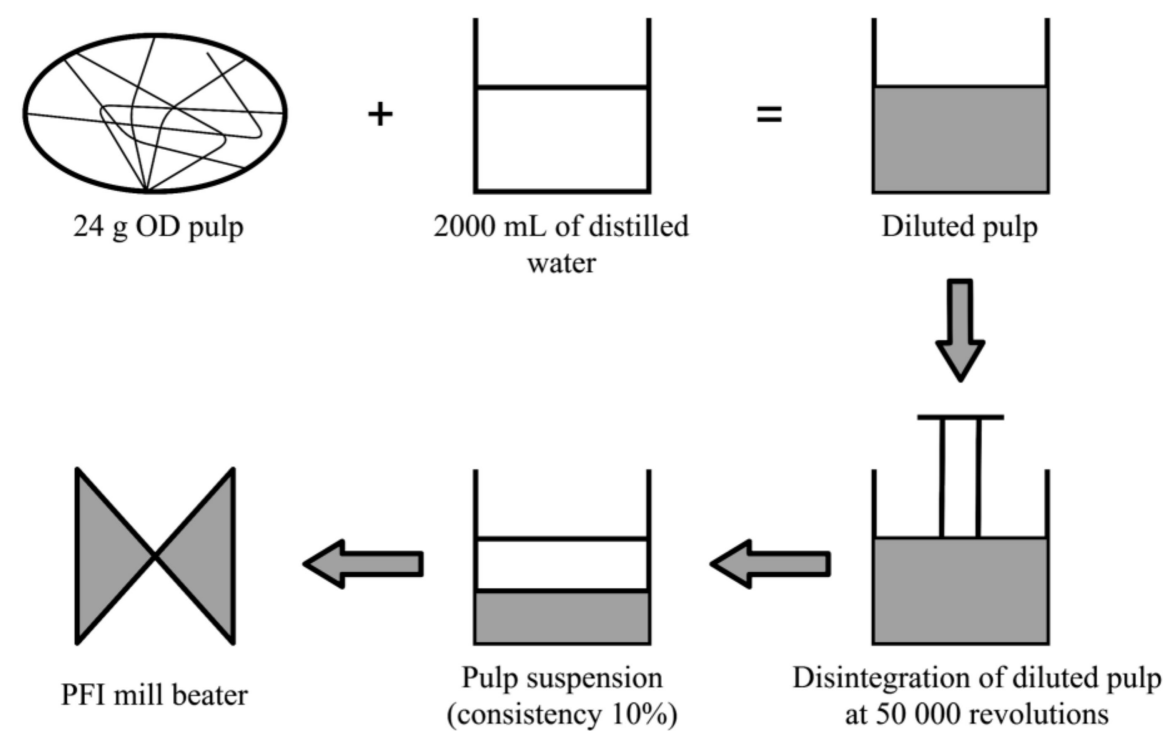

Figure 5. Beating process of the Kenaf pulps.

\subsection{Chemical Treatment}

The PVA powder was added to the pulp at weight percentage concentrations between $3 \%$ and $12 \%$. The weight percentage concentration of PVA was calculated based on Equation (3), according to the OD weight of pulp. It was mixed with $200 \mathrm{~mL}$ of distilled water at $90^{\circ} \mathrm{C}$ while using magnetic stirrer for $2 \mathrm{~h}$, in order to produce homogenous PVA solution as shown in Figure 6. The PVA solution was then cooled at room temperature. In order produce the pulp suspension, $20.8 \mathrm{~g}$ of pulp was diluted with $1735 \mathrm{~mL}$ of distilled water. A mixer was used to disintegrate PVA solution and pulp suspension at 50,000 revolutions.

$$
\% \mathrm{PVA}=\frac{\text { Weight of PVA }(g)}{\text { Total weight of pulp }(g)} \times 100
$$



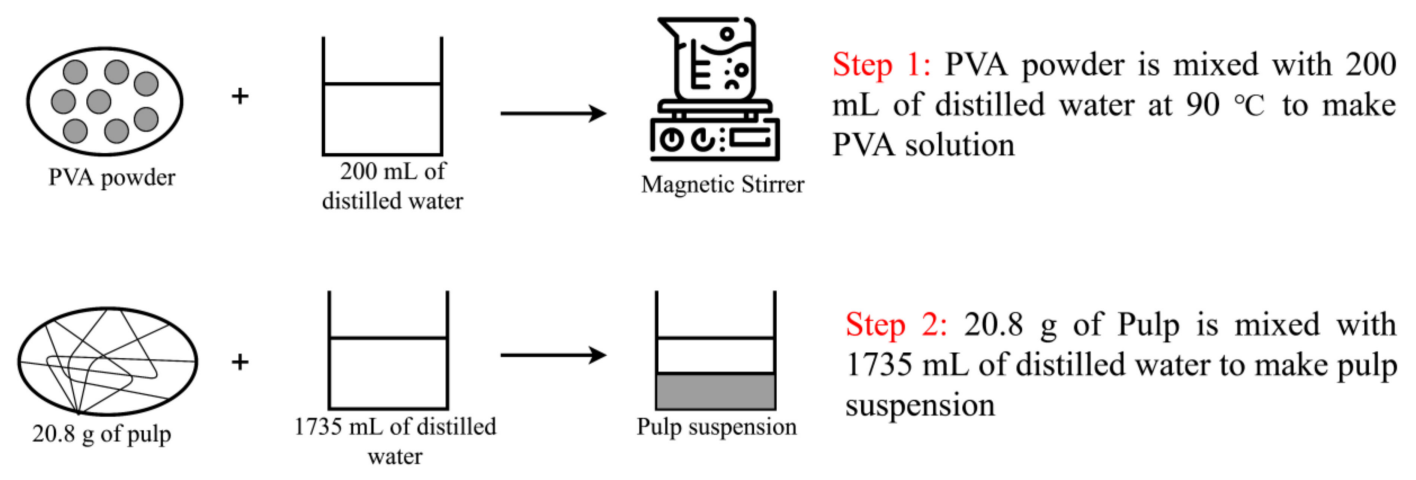

Step 2: $20.8 \mathrm{~g}$ of Pulp is mixed with $1735 \mathrm{~mL}$ of distilled water to make pulp suspension

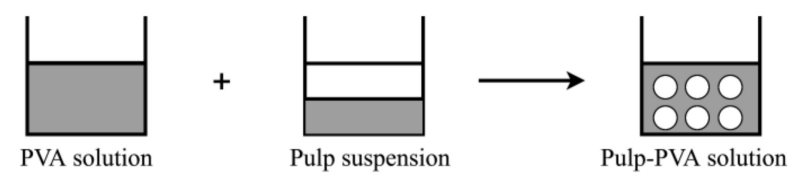

Step 3: PVA solution and pulp suspension are mixed to make pulpPVA solution

Figure 6. Polyvinyl alcohol (PVA) treatment on the Kenaf pulps.

\subsection{Preparation of Handsheets}

Figure 7 shows the process for producing handsheets. Handsheets with the grammage of $52 \mathrm{~g} / \mathrm{m}^{2}$ were produced according to TAPPI T205 [37]. The pulp-PVA solution was poured into the stock divider and then mixed with $12 \mathrm{~L}$ of distilled water. In total, $867 \mathrm{~mL}$ of pulp suspension was obtained from the stock divider in order to produce the handsheets on paper machine.

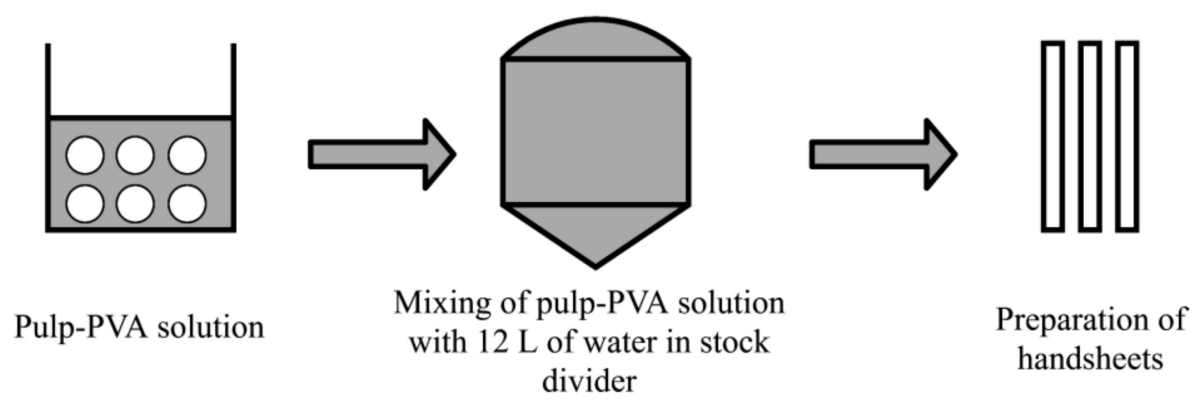

Figure 7. Papermaking process.

\section{Experimental Setup}

\subsection{Pre-Processing of Oil and Paper}

Kenaf papers obtained at different beating revolutions and different weight percentage concentration of PVA were examined for their physio-mechanical properties and AC breakdown voltage. The Kenaf papers were cut into the width and length dimensions of $15 \mathrm{~mm}$ and $150 \mathrm{~mm}$, respectively. The Kenaf papers have thicknesses ranging from $92.99 \mu \mathrm{m}$ to $175.90 \mu \mathrm{m}$ with grammage of $52 \mathrm{~g} / \mathrm{m}^{2}$. Kraft paper with thickness and width dimensions of $70 \mu \mathrm{m}$ and $16 \mathrm{~mm}$ with a grammage of $52 \mathrm{~g} / \mathrm{m}^{2}$ was also tested for comparison purpose. The Kraft paper was cut individually into the length of $150 \mathrm{~mm}$. Mineral Oil (MO) was used to impregnate all of the papers. The pre-processing procedure of the oil and paper can be seen in Figure 8.

First, the $\mathrm{MO}$ was filtered three times by a membrane filter with a pore size of $0.2 \mu \mathrm{m}$. Next, the $\mathrm{MO}$ was dried in an air circulating oven at $85^{\circ} \mathrm{C}$ for $48 \mathrm{~h}$. The papers were dried in a vacuum oven at $105^{\circ} \mathrm{C}$ at the pressure of $0.08 \mathrm{kPa}$ for $48 \mathrm{~h}$. The impregnations of both types of papers were carried out by the $\mathrm{MO}$ in an air circulation oven at $85^{\circ} \mathrm{C}$ for $24 \mathrm{~h}$. 


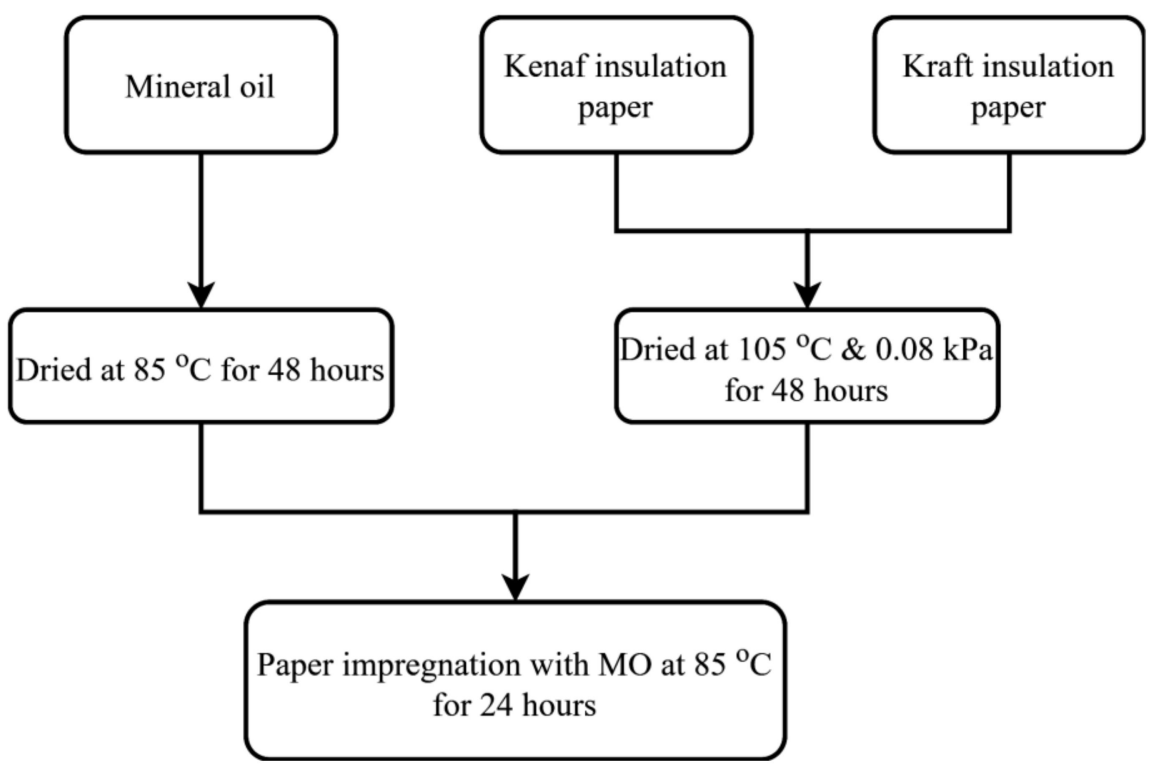

Figure 8. Pre-processing of oil and paper.

\subsection{AC Breakdown Voltage}

The AC breakdown voltage was performed with BAUR DPA 75 C tester based on IEC 60156 [38]. Before the test was carried out, the test cell was drained, whereby the walls, electrodes, and test cells were rinsed three times with MO. In order to prevent the formation of bubbles, $400 \mathrm{~mL}$ of pre-processed MO was poured slowly into the test cell. The distance between the electrodes was adjusted according to the thickness of the paper sample. The AC breakdown test was carried out with two layers paper, since the measurement for one layer could not be computed since the thickness is too small. The test was carried out using spherical electrodes with diameter of $12.5 \mathrm{~mm}$, with both sides facing each other. The voltage ramping rate during the test was $2 \mathrm{kV} / \mathrm{s}$. The oil-impregnated paper was placed in between the electrodes, as shown in Figure 9. The paper sample was moved to other positions after each time of the breakdowns. A total of $20 \mathrm{AC}$ breakdown voltages were recorded and the average value was used for analysis.

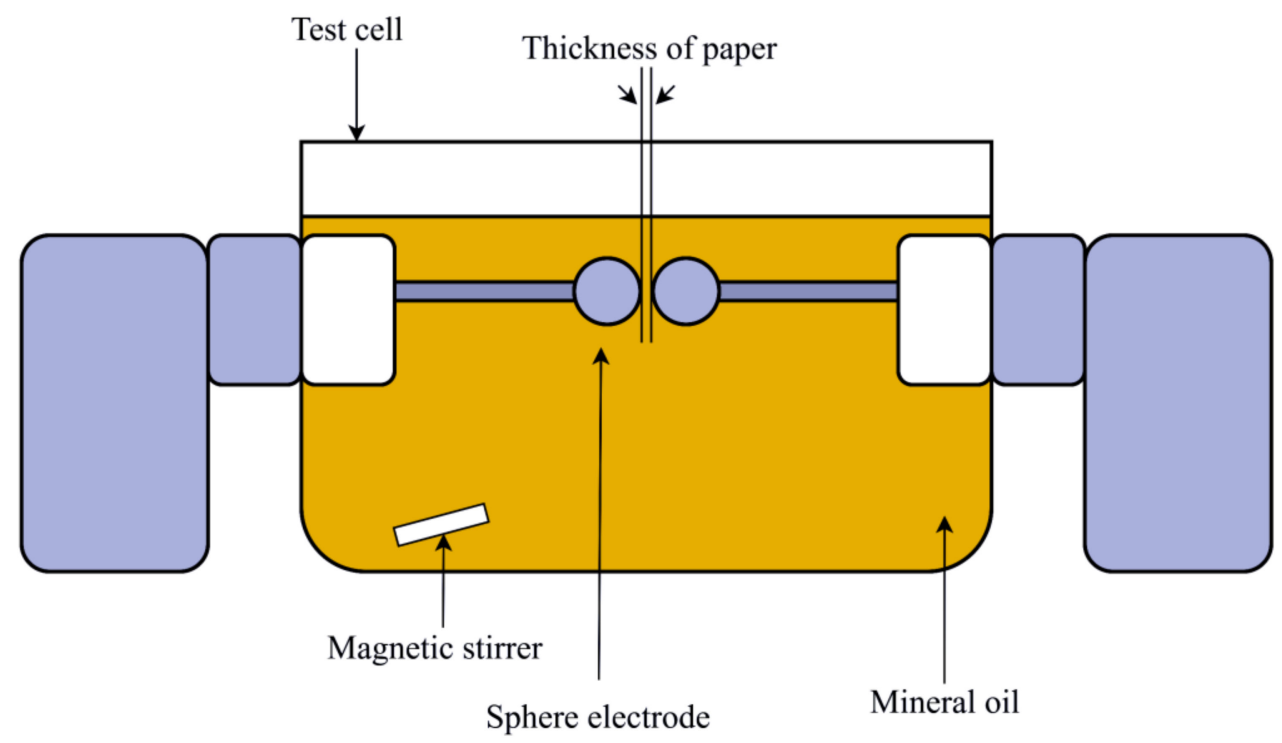

Figure 9. AC breakdown voltage test of paper. 


\subsection{Scanning Electron Microscopy (SEM)}

A Scanning Electron Microscope (SEM) was used to observe the arrangement of fibers and its bonds. The SEM imaging was carried out with COXEM EM-30ax. For the preparation of samples for SEM imaging, an ion coater COXEM SPT-20 was used to cover the surface of the paper sample with a thin conductive layer in order to avoid charging effect on the obtained image.

\subsection{Apparent Density of Paper}

Ten paper samples were cut into the dimensions of $10 \times 10 \mathrm{~cm}$, as shown in Figure 10. The thickness of each paper sample was measured by L\&W micrometer based on TAPPI T411 [39]. The sample's grammage was determined based on Equation (4), by first measuring the sample's mass and area, as per TAPPI T 410 [40]. The mass of each sample was measured using A\&D analytical balance. The apparent density was calculated based on Equation (5).

$$
\begin{aligned}
\operatorname{Grammage}\left(\mathrm{g} / \mathrm{m}^{2}\right) & =\frac{\operatorname{Mass}(\mathrm{g})}{\operatorname{Area}\left(\mathrm{m}^{2}\right)} \\
\text { Apparent density }\left(\mathrm{g} / \mathrm{cm}^{3}\right) & =\frac{\operatorname{Grammage}\left(\mathrm{g} / \mathrm{m}^{2}\right)}{\text { Thickness }(\mu \mathrm{m})}
\end{aligned}
$$
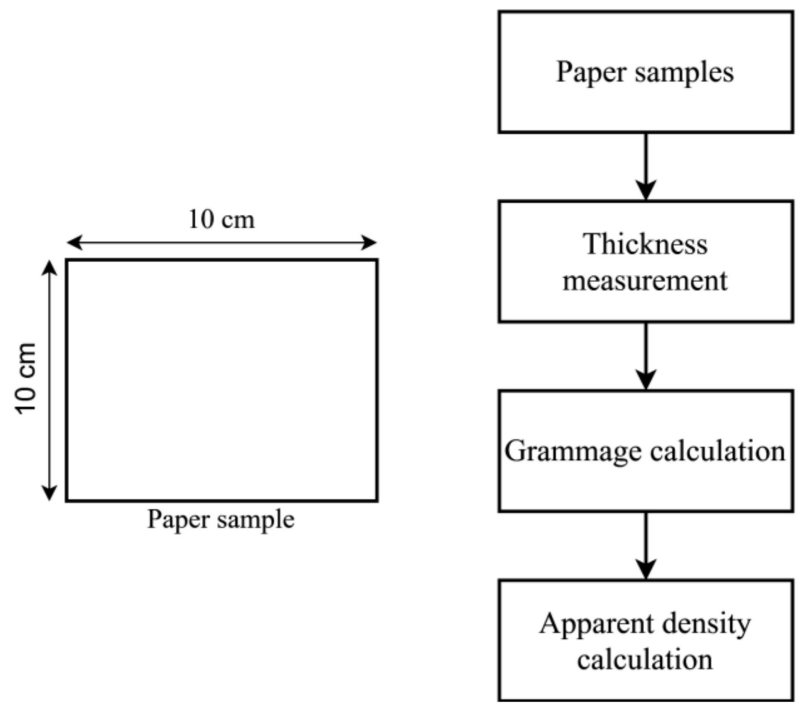

Figure 10. Grammage and apparent density measurements.

\subsection{Mechanical Properties of Paper}

A Buchel B.V horizontal tensile tester was used for measuring the paper tensile strength, as per TAPPI T494 [41]. The measuring gap length of the test was set to $100 \mathrm{~mm} \pm 1 \mathrm{~mm}$. The length and width of the paper sample were $150 \mathrm{~mm}$ and $15 \mathrm{~mm}$ respectively, as shown in Figure 11. The crosshead speed was set to $20 \mathrm{~mm} / \mathrm{min}$. [41]. The test was carried out at $23^{\circ} \mathrm{C} \pm 1{ }^{\circ} \mathrm{C}$ and $50 \% \pm 2 \%$ relative humidity. The TI was calculated based on Equation (6).

$$
T I(N m / g)=\frac{\text { Tensile strength }(\mathrm{N} / \mathrm{m})}{\text { Grammage }\left(\mathrm{g} / \mathrm{m}^{2}\right)}
$$




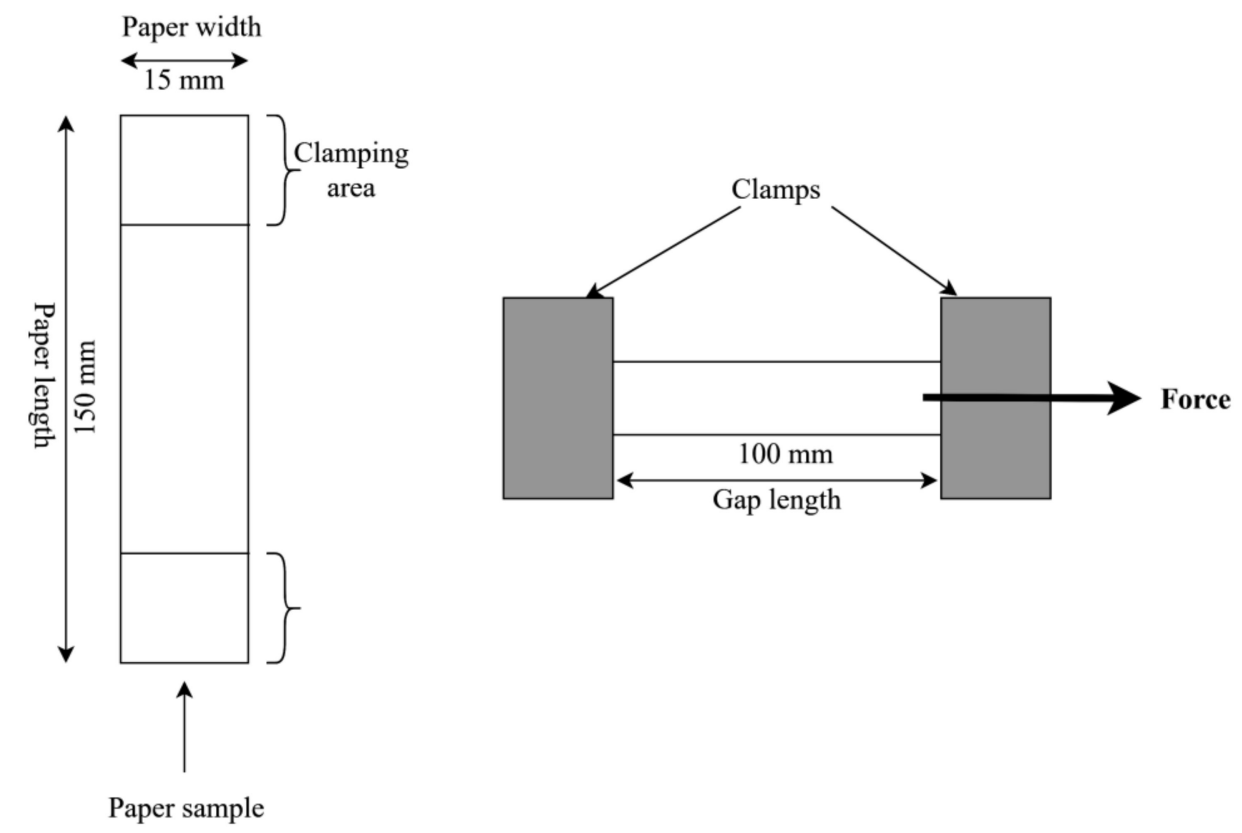

Figure 11. Tensile strength measurement.

The burst strength is the maximum hydrostatic pressure that is required to produce rupture of the paper when a controlled and constantly increasing pressure is applied through a rubber diaphragm to a circular area of $30.5 \mathrm{~mm}$, as seen in Figure 12. The burst strength of paper was measured by Frank burst machine based on TAPPI T 403 [42]. A total of 10 paper samples with dimension of $62 \mathrm{~mm} \times 62 \mathrm{~mm}$ were prepared. The test was carried out at $23{ }^{\circ} \mathrm{C} \pm 1{ }^{\circ} \mathrm{C}$ and $50 \% \pm 2 \%$ relative humidity. The paper sample was placed in between the clamps with a clamping pressure of not more than $1200 \mathrm{kPa}$ [42]. A constant increasing hydraulic pressure was applied to the paper through a rubber diaphragm, until the paper bursts. The BI was determined based on Equation (7).

$$
B I\left(k P a . m^{2} / g\right)=\frac{\text { Burst Strength }(k P a)}{\text { Grammage }\left(g / m^{2}\right)}
$$

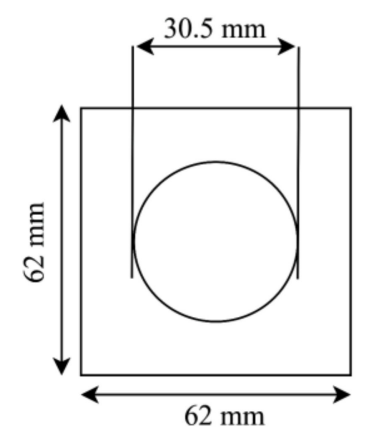

Paper sample

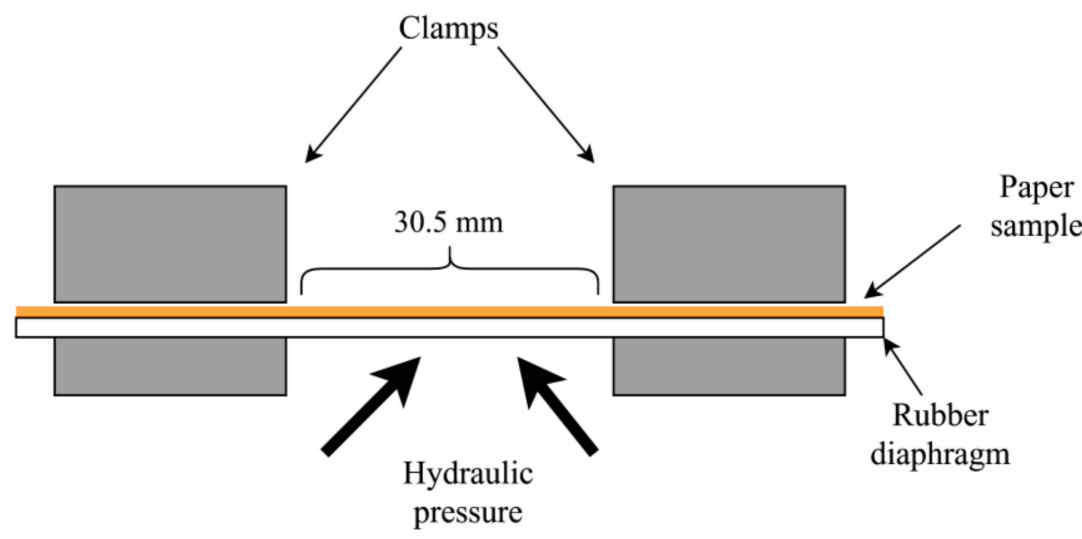

Figure 12. Burst strength measurement.

The tear strength is the force that is required to tear the paper. The tear strength of the paper was measured by Elmendorf tearing tester, as per TAPPI T414 [43]. Ten samples with the dimensions of $63 \mathrm{~mm} \times 50 \mathrm{~mm}$ were prepared. The test was carried out at $23^{\circ} \mathrm{C} \pm 1{ }^{\circ} \mathrm{C}$ and $50 \% \pm 2 \%$ relative humidity. The paper sample was placed in between the clamps with the same clamping pressure 
of $0.55 \mathrm{MPa}$ on both sides, as seen in Figure 13. A slight cut in the middle of the paper was made before the force was applied [43]. The tear strength was recorded and the TeI was determined based on Equation (8).

$$
\operatorname{TeI}\left(m N . m^{2} / g\right)=\frac{\text { Tear Strength }(m N)}{\text { Grammage }\left(g / m^{2}\right)}
$$

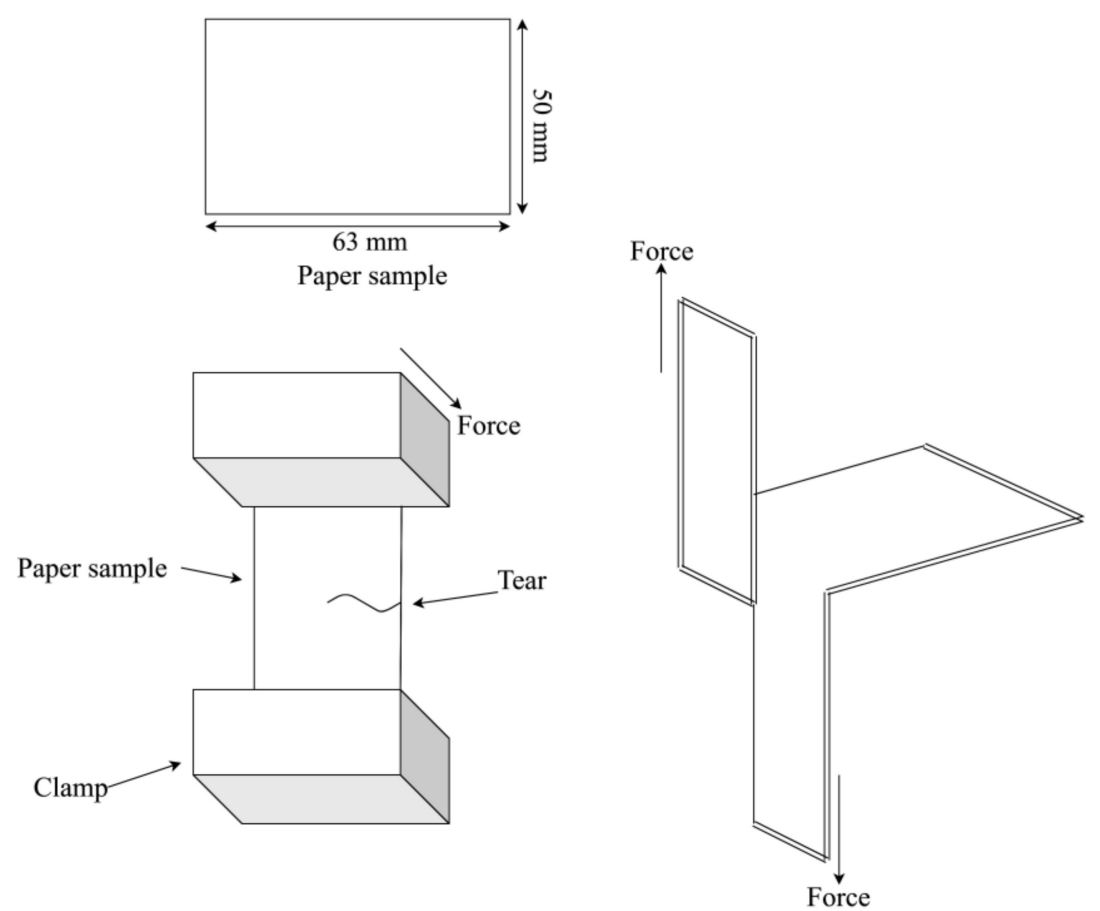

Figure 13. Tear strength measurement procedure.

\section{Results and Discussion}

\subsection{Kenaf Pulp Properties}

Table 1 illustrates the characteristics of Kenaf fibers. The standard Kenaf bast fibers are typically up to $3 \mathrm{~mm}$ long with width between $13.8 \mu \mathrm{m}$ and $19.5 \mu \mathrm{m}[10,18]$. According to [10,18], the lumen width of the Kenaf bast fibers is between $4.3 \mu \mathrm{m}$ and $10.1 \mu \mathrm{m}$, while the average cell wall thickness is $11.90 \mu \mathrm{m}$ [44]. All the properties of the tested Kenaf fibers are within the ranges, as in [10,18], except for the cell wall thickness, which is slightly low.

Table 1. Fiber characteristics.

\begin{tabular}{cc}
\hline Property & Value \\
\hline Fiber length $(\mathrm{mm})$ & $2.964 \pm 0.482$ \\
\hline Fiber width $(\mu \mathrm{m})$ & $12.24 \pm 2.84$ \\
\hline Lumen width $(\mu \mathrm{m})$ & $8.08 \pm 2.12$ \\
\hline Cell wall thickness $(\mu \mathrm{m})$ & $2.08 \pm 0.7$ \\
\hline
\end{tabular}

Without beating, the freeness of Kenaf pulp is $718 \mathrm{~mL}$ [45]. It is quite high, and it indicates that the paper is porous to liquids. As a result, the paper can lose its strength if impregnation is carried with MO. The standard range of pulp freeness for a strong paper with good mechanical strength is between $100 \mathrm{~mL}$ and $200 \mathrm{~mL}$ [45]. The strength of the paper is one of the main requirements for transformers application. Beating could reduce the freeness of the pulp, which eventually increases the paper's 
mechanical strength $[33,45]$. The beating of 12,000 revolutions could decrease the freeness of the pulp up to $92 \%$, as the beating of the pulps helps to break the fibers into more fibrous fragments [45].

\subsection{Morphological Analysis of Kenaf Fiber}

Figure 14a illustrates the SEM images of the unbeaten Kenaf paper taken at magnification of $\times 2000$. The fiber width is between $8.6 \mu \mathrm{m}$ and $16.2 \mu \mathrm{m}$ with an average of $12.4 \mu \mathrm{m}$ that is close to the measurement by a fiber classifier, as shown in Table 1 . The fiber walls are free from fibrils that suggest that there is no fibrillation on fiber walls and signify a clean network of fibers as shown in Figure 14a. Because the fiber wall for unbeaten pulp is not fibrillated, the pores are quite apparent and could promote the flow of oils. After beating, the fibrillation starts to occur as shown in Figure 14b. There are a number of fibrilar bridges on the fiber cell walls, which promote new bonding and subsequently increase the strength of the Kenaf paper through an increment of the contact area and density. The structures of the fiber walls surface and the cell walls of unbeaten pulp are quite smooth when compared to beaten pulps, as shown in Figure 14.

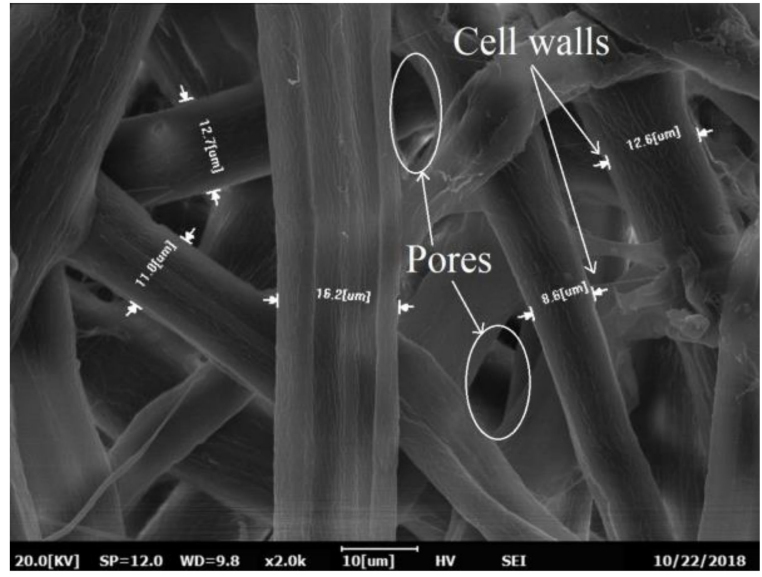

(a)

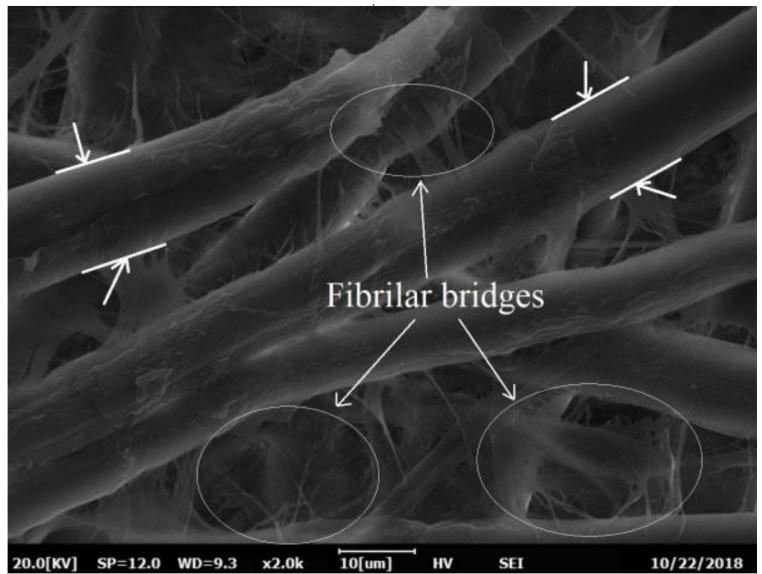

(b)

Figure 14. Scanning electron microscope (SEM) images of Kenaf paper at magnification of $\times 2000$

(a) unbeaten pulp (b) beaten at 12,000 revolutions.

\subsection{Effect of Mechanical and Chemical Treatments on the Structure of Kenaf Fibers}

Figure 15 shows the SEM images of the Kenaf paper under mechanical treatments. Figure 15b illustrates that the beating of 6000 revolutions improves the number of fibrils, which lead to the increment of the fiber joints. The number of fibrils is further enhanced after 12,000 revolutions of beating with the increment of the fiber flexibility, as seen in Figure 15c. The new fibrils are bonded to each other to increase the contact area. The increment of the contact area results in the increment of apparent density of paper. The beating process affects fiber surfaces, as there are many fibrils on cell walls, leaving behind uneven surfaces on the fiber cell wall. These fibrils bond to form the fibrilar bridges, resulting in an increment of the fibril network. As the fibrils bonding increases, the BI of the paper increases. The beating process results in fibrillation on the fiber cell walls and lead to the improvement of the paper tensile strength, as shown in Figure 15c [45]. 


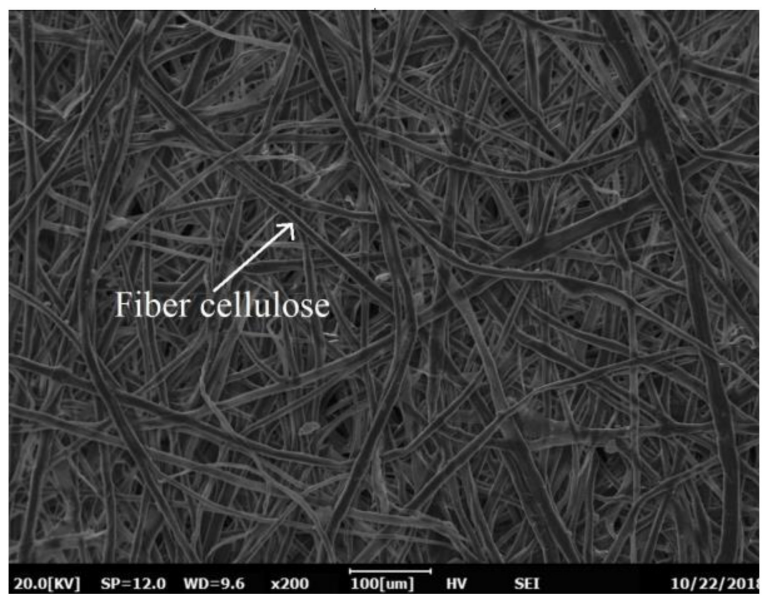

(a)

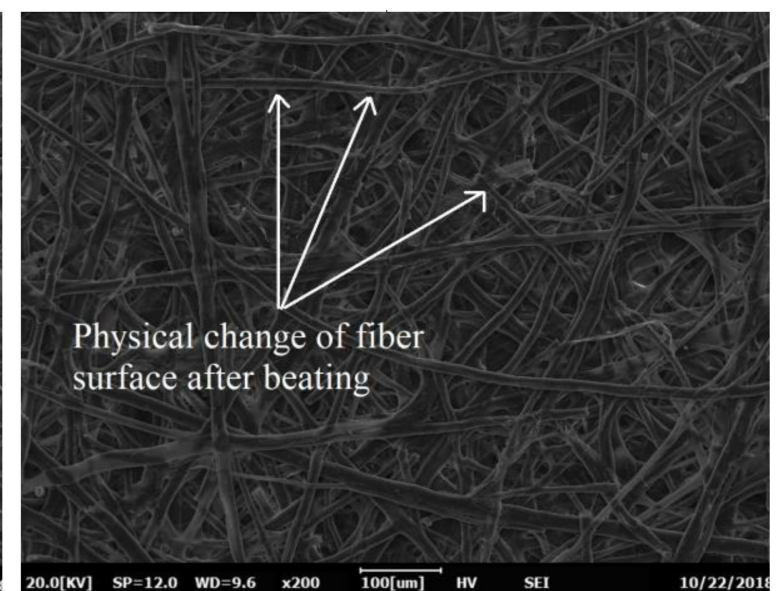

(b)

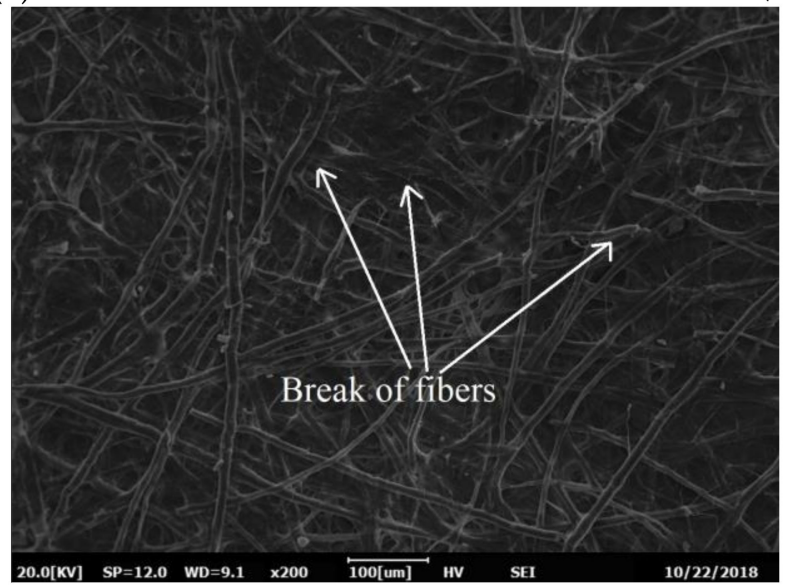

(c)

Figure 15. SEM images of Kenaf paper: (a) unbeaten pulp; (b) beaten at 6000 revolutions; and, (c) beaten at 12,000 revolutions.

The physio-mechanical properties of the Kenaf paper at different beating revolutions have been previously examined in [45]. It is found that the beating at 12,000 revolutions could provide the highest improvements of the TI and BI as well as density. On the other hand, the TeI and thickness decrease. The beating process increases the flexibility of the fiber, bonding, and lead to denser fiber. As a result, high tensile forces and pressures are required to break the Kenaf fibers. On the other hand, the beating process results in shorter fibers whereby less force is required to tear the paper and, hence, lower TeI. Because the Kenaf paper beaten at 12,000 revolutions results in the highest performance, it has been chosen for further improvement through introduction of PVA.

Figure 16 illustrates the SEM images of Kenaf paper after chemical treatment. The introduction of the PVA to the pulp promotes fibrillation bridges through the presence of several cellulose strands and subsequently enhances the network bonding of the fibers. Apparent fibrils are bonded on the fiber cell walls, as seen in Figure 16a,b. This network increases the number of bonds and reduces the number of the pores in the Kenaf paper. 


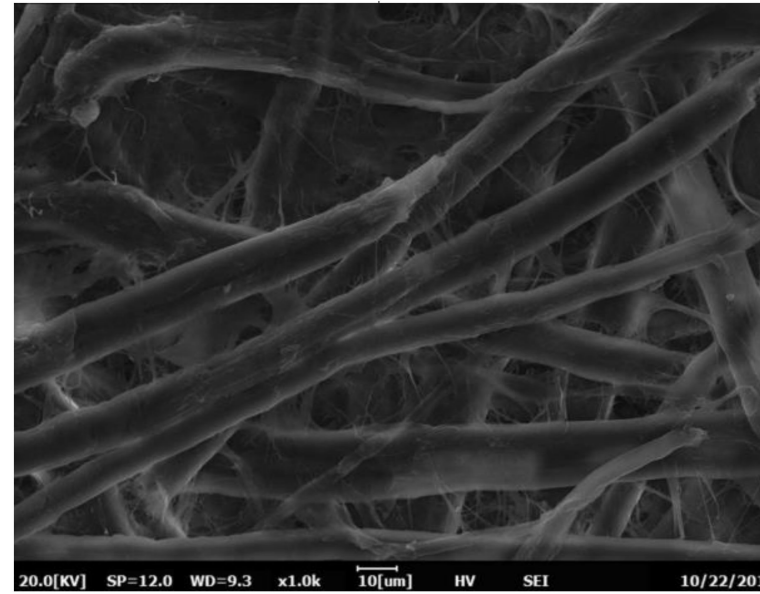

(a)

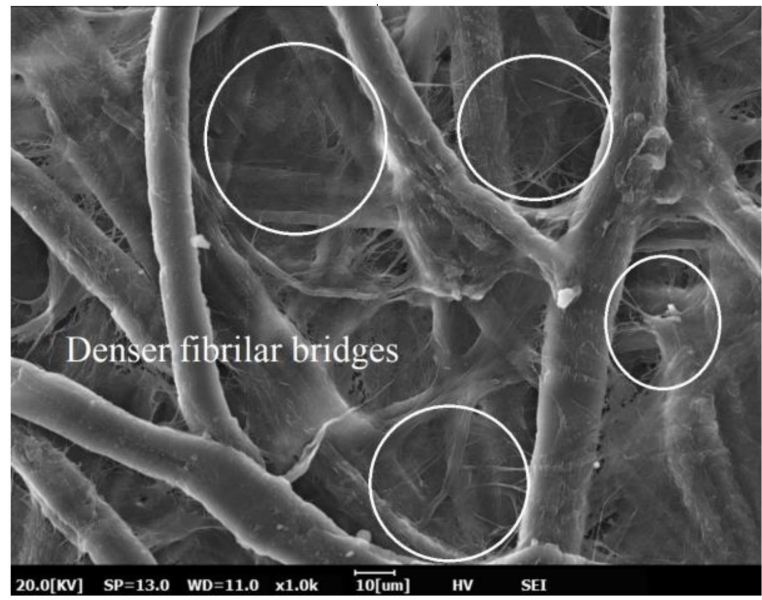

(b)

Figure 16. SEM images of Kenaf paper: (a) beaten at 12,000 revolutions; and, (b) beaten at 12,000 revolutions and $12 \%$ PVA.

\subsection{Physio-Mechnical Properties of Kenaf Paper with PVA}

The Kenaf paper thickness decreases with the addition of 3\% of PVA and it increases as the PVA increases from $9 \%$ to $12 \%$ of PVA, as shown in Figure 17. The thickness of the paper increases by $7.09 \%$ as $12 \%$ of PVA is introduced. Initially, the density of the Kenaf paper slightly increases as $3 \%$ of PVA is introduced. The density of the Kenaf paper maintains almost unchanged as the PVA increases from 3\% to $9 \%$. The density of the Kenaf paper significantly decreases by $19.44 \%$ as $12 \%$ of PVA is introduced.

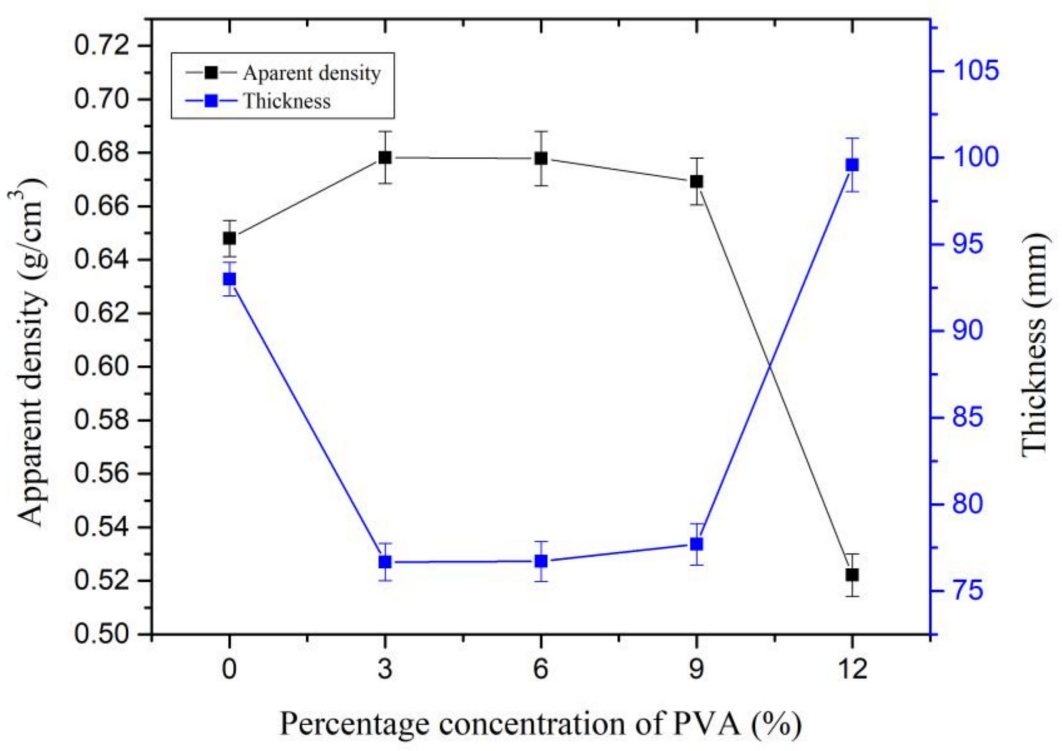

Figure 17. Thickness and density at different weight percentage concentration of PVA.

\subsection{Mechanical Properties of Kenaf Paper with PVA}

The TI of Kenaf paper initially decreases by $7.01 \%$ as 3\% of PVA is introduced. As the weight percentage concentration of PVA increases from $3 \%$ to $12 \%$, the TI of Kenaf paper increases, as shown in Figure 18. Based on SEM imaging in Figure 18, fibrillation occurs as PVA is introduced and leads to the increment of hydrogen bonding, which subsequently increases the strength of the Kenaf paper. As compared to without PVA, the highest increment of TI of paper is $1.89 \%$ at $12 \%$ of PVA. The coefficient of variation is between $1.8 \%$ and $4.3 \%$ as the weight percentage concentration of PVA 
increases to $12 \%$. However, the TI of Kenaf paper is still considered low when compared to Kraft paper with the strength of $113 \mathrm{Nm} / \mathrm{g}$.

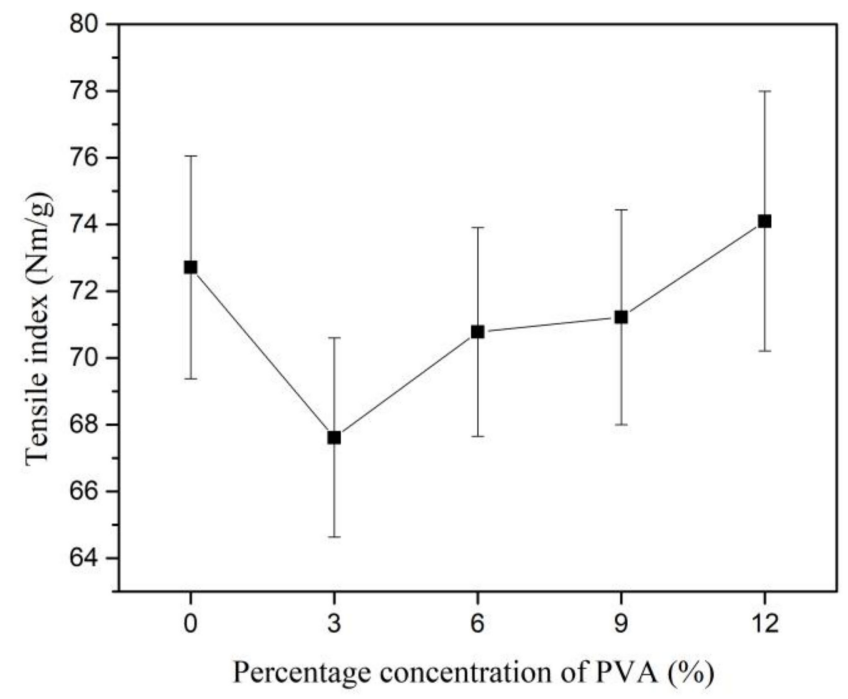

Figure 18. Tensile index of Kenaf paper at different weight percentage concentration of PVA.

The BI of Kenaf paper increases steadily with the increment of weight percentage concentration of PVA, as shown in Figure 19. The introduction of PVA in the paper tends to increase the fibrilar bridges and increases hydrogen bonding. Consequently, higher pressure is required to break the bonding between fibers. The BI of Kenaf paper increases by $14.54 \%$ as $12 \%$ of PVA is introduced. The coefficient of variation fluctuates between $24.5 \%$ and $15.7 \%$ as the weight percentage concentration of PVA is increased to $12 \%$.

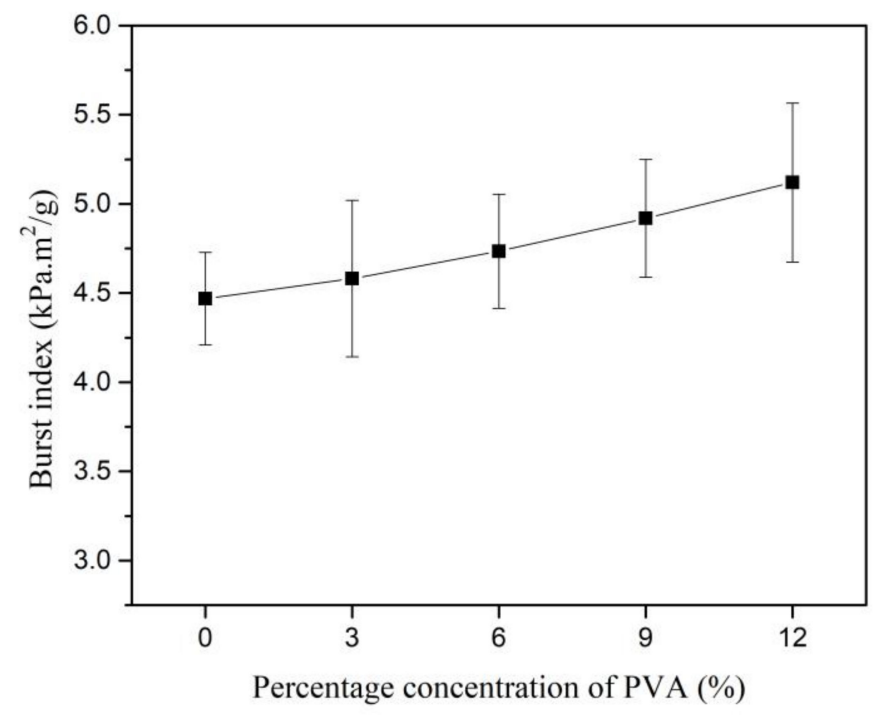

Figure 19. Burst index at different weight percentage concentration of PVA.

The pattern of the TeI is similar to the TI of Kenaf paper, as shown in Figure 20. The TeI initially decreases as the weight percentage concentration of PVA is increased to 3\%. The TeI slightly increases at much lower rate than TI as the weight percentage concentration of PVA increases from $3 \%$ to $12 \%$. The range for the coefficient of variation is between $1.5 \%$ and $7.5 \%$ as the weight concentration of PVA is increased up to $12 \%$. TeI is related to the length of fibers. The addition of PVA to the pulp does not 
further increase the fiber length; therefore, it is expected that TeI would not be increased as the weight percentage concentration of PVA increases.

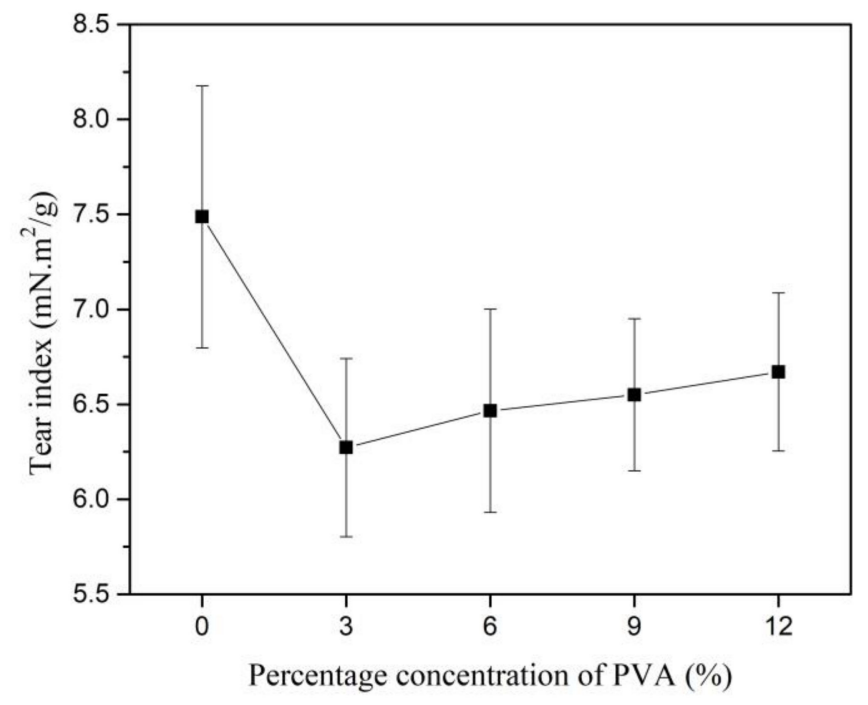

Figure 20. Tear index at different weight percentage concentration of PVA.

\subsection{AC Breakdown Voltage of Kenaf Paper without PVA}

The AC breakdown voltages of the MO impregnated Kenaf papers for two and three layers are observed, as seen in Figure 21. The pattern of the Kenaf and Kraft paper still comply with the existing multiple layer effect whereby the AC breakdown voltage increases with the increment of paper layers [46-49]. The AC breakdown voltage patterns of Kenaf paper for both layers are quite similar as the beating revolution increases. With the increment of beating revolution to 3000, the AC breakdown voltages of Kenaf paper for two and three layers slightly increase to $9.8 \%$ and $2 \%$, respectively. As the beating revolution increases to 6000, the AC breakdown voltages of Kenaf paper for two and three layers decrease to $22.8 \%$ and $17.3 \%$, respectively. At beating of 12,000 revolutions, the AC breakdown voltage of Kenaf paper for two layers is $14.92 \%$ higher than Kraft paper. Meanwhile, the AC breakdown voltage Kraft paper for three layers is $20.49 \%$ higher than the Kenaf paper. The paper condition after the AC breakdown tests can be seen in Figure 22.

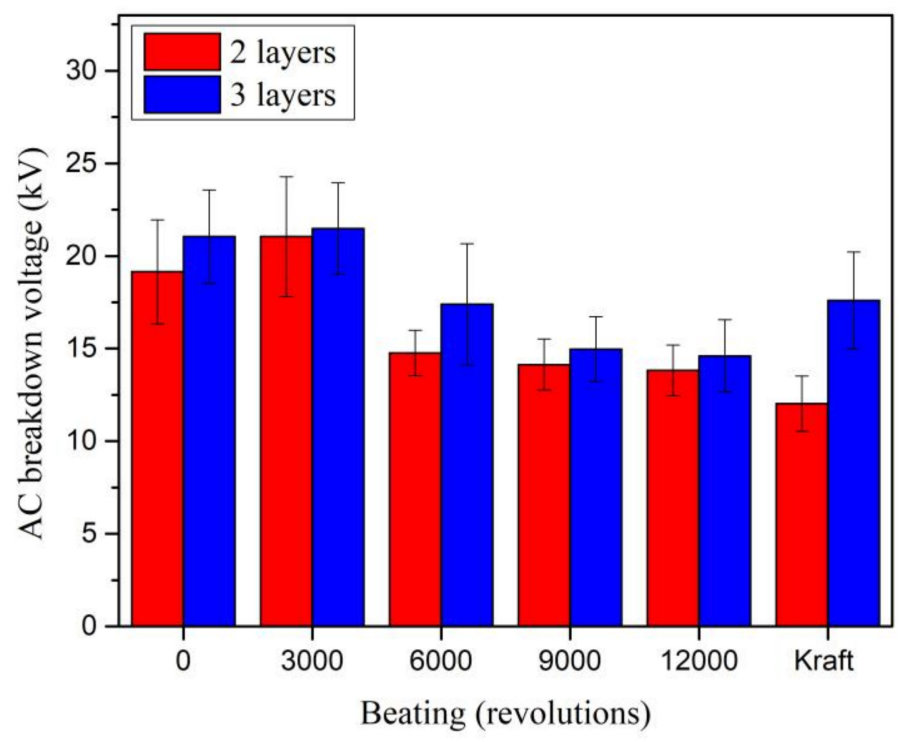

Figure 21. AC breakdown voltage of Kenaf and Kraft papers at different layers and beating revolutions. 


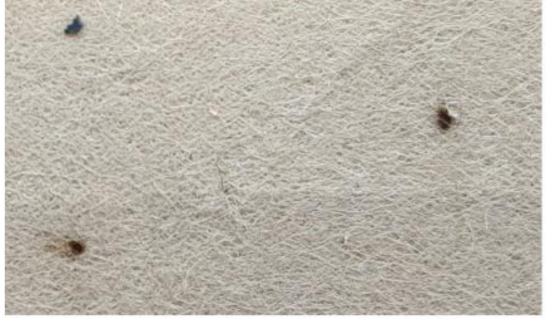

(a)

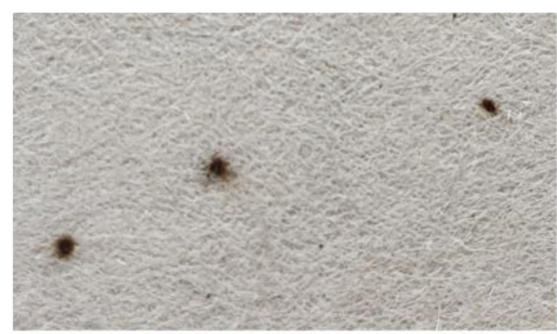

(b)

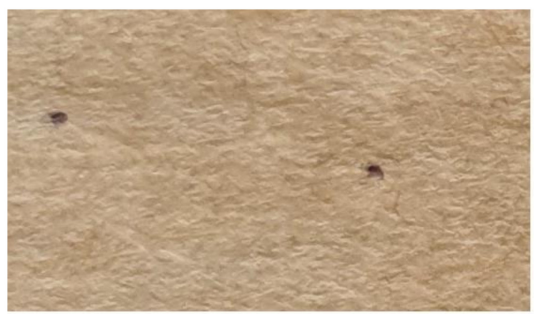

(c)

Figure 22. Paper condition after breakdown tests: (a) Unbeaten Kenaf paper; (b) Kenaf paper with 12,000 revolutions of beating; and, (c) Kraft paper.

The AC breakdown strength was obtained by dividing the AC breakdown voltage with the thickness of paper, since it was set as the gap distance. Similar as AC breakdown voltage, the AC breakdown strengths of Kenaf paper for two and three layers slightly increase to $42.05 \%$ and $42.12 \%$ as the beating increases to 3000 revolutions as shown in Figure 23. The AC breakdown strengths of Kenaf paper for two and three layers fluctuate between $72.4 \mathrm{kV} / \mathrm{mm}$ and $74.3 \mathrm{kV} / \mathrm{mm}$ as the beating revolution increases from 6000 to 12,000. At the beating of 12,000 revolutions, the AC breakdown strengths of Kenaf paper for two and three layers are $13.49 \%$ and $37.52 \%$ lower than the Kraft paper.

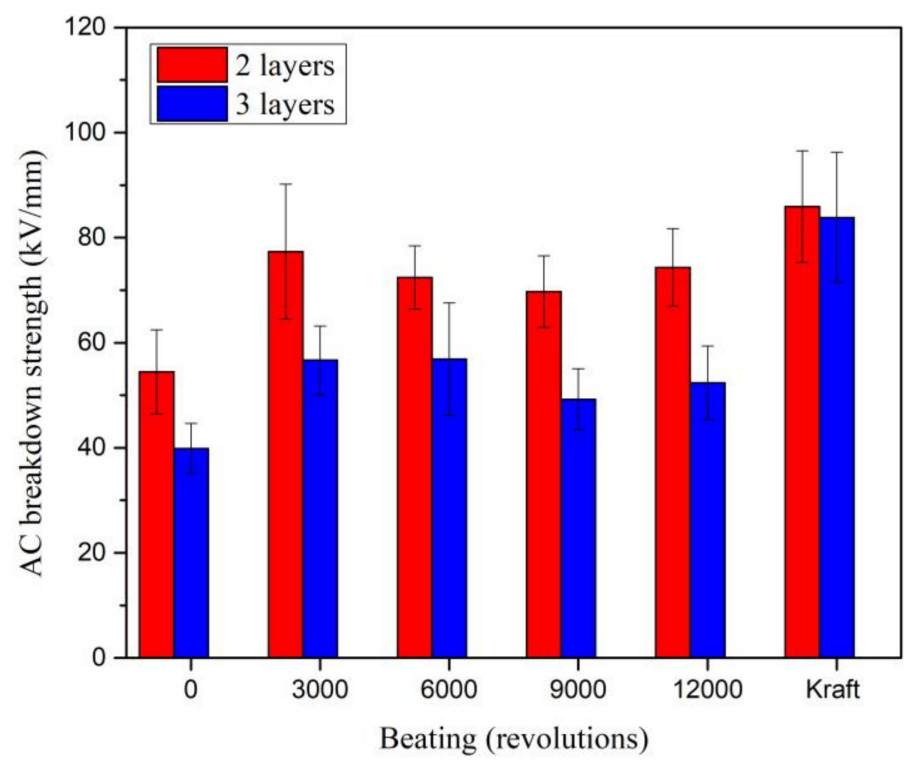

Figure 23. AC breakdown strength of Kenaf and Kraft papers at different layers and beating revolutions.

\subsection{AC Breakdown Voltage of Kenaf Paper with PVA}

The AC breakdown voltage of MO impregnated Kenaf paper with PVA weight percentage concentrations of 3\% and 6\% can be seen in Figure 24. The AC breakdown voltages of Kenaf paper for 
two and three layers increase almost linearly with the increment of the weight percentage concentration of PVA. At PVA weight percentage concentration of $6 \%$, the AC breakdown voltages of Kenaf paper for 2 and 3 layers increase by $8.2 \%$ and $8.4 \%$. The AC breakdown voltage of Kenaf paper for 2 layers at PVA weight percentage concentration of $6 \%$ is $24.36 \%$ higher than Kraft paper. On other hand, the AC breakdown voltage of Kenaf paper for three layers is $10.03 \%$ lower than Kraft paper at the same weight percentage concentration of PVA. Figure 25 illustrates the paper condition after the breakdown tests.

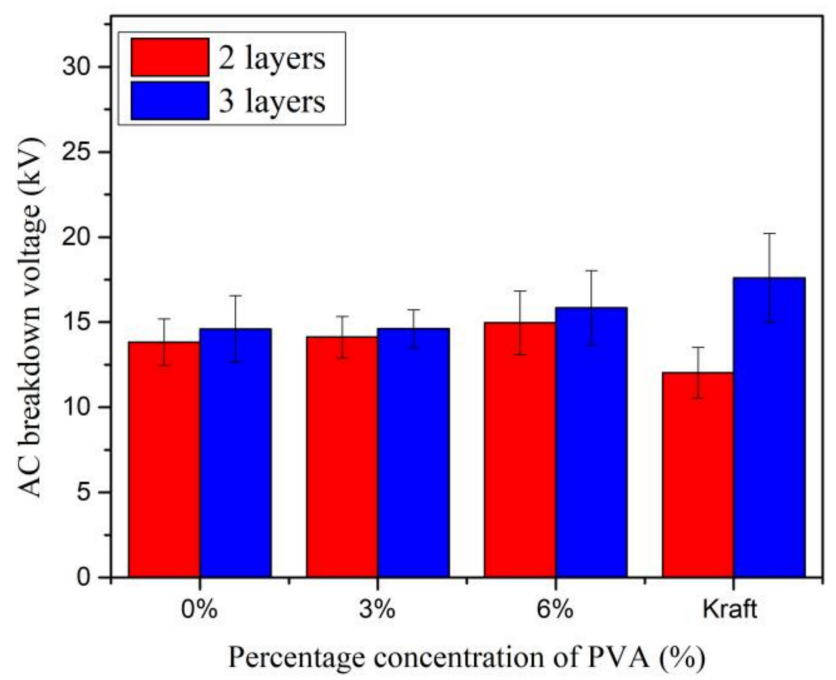

Figure 24. AC Breakdown voltage of Kenaf and Kraft papers at different weight percentage concentration of PVA.

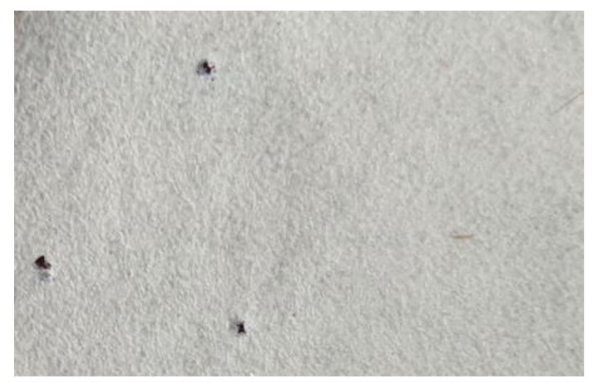

(a)

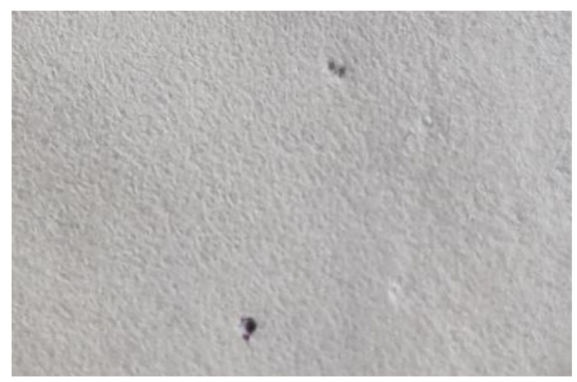

(b)

Figure 25. Paper condition after breakdown tests: (a) Kenaf paper with weight percentage concentration of $3 \%$ of PVA and (b) Kenaf paper with weight percentage concentration of $6 \%$ of PVA.

The AC breakdown strengths increment patterns of Kenaf paper for two and three layers are quite apparent, as shown in Figure 26. As the PVA weight percentage concentration increases to $6 \%$, the AC breakdown strengths of Kenaf paper for two and three layers increase by $34.88 \%$ and $44.37 \%$. Similar to the AC breakdown voltage, the AC breakdown strength of Kenaf paper for two layers is $16.68 \%$ higher than Kraft paper at the same PVA weight percentage concentration. The AC breakdown strength of Kraft paper is $10.87 \%$ higher than the AC breakdown strength of Kenaf paper for three layers. 


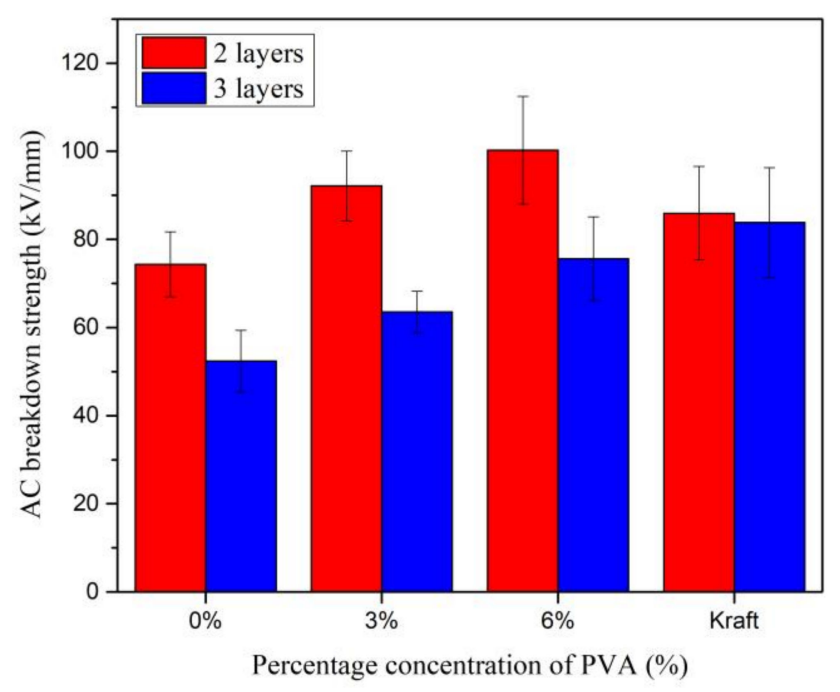

Figure 26. AC Breakdown strength of Kenaf and Kraft papers at different weight percentage concentration of PVA.

\section{Discussion}

The mechanical properties of the paper arise from the interfiber bonding which could occur between two fibers through either the van der Waals interaction or molecular linkage [50]. Fiber bonding could affect the optical, electrical, and structural properties of the paper [50-52].

Interfiber bonding occurs once the water is extracted during the papermaking process, whereby the surface tension forces pulling fibers together [53]. Through the drying process, the pulp fibers could laterally shrink, which cause shear stress to the bonding area. It is due to the differences between the tendency of lateral and longitudinal shrinkage of fibers [54]. The shrinkage is dependent upon the revolutions to which the wet fiber wall swells, and it is influenced by internal fibrillation as well as the composition of the chemical properties of the fiber wall. Shrinking forces are the strongest in the peripheral area of bond and the bonding edges bear the load first when loaded. Shrinkage stress induces axial compression force on the crossed fibers, and it can cause deformations in the segments of bonded fibers [55]. Stresses at the bonding area and fiber wall change the mechanical characteristics of the bonded fibers and subsequently affect the strength of the paper [56]. Activation is one of the related fiber characteristics of a network [57,58]. The kinky, curly, or deformed fiber segments, which cannot be loaded to the networks, could originally be changed into active network components [55-57]. The process of activation occurs during the drying process of papermaking. Fiber morphology could affect the required drying stress to enable the free segments. Activating the free segments not only makes the segment straighter and more capable of holding load, but it can also raise the order of cellulose and hemicelluloses within the fibrils and decrease the fibril angle.

Flexible fibers may form bonds, fibrils, and fines from bridges between fibers. Through the increment of the fibers contact, the fibers surface physically changed, which affect the physical properties of paper. Delamination, swelling, and dislocation among the individual fibers could be performed through beating, which results in increment of fibers flexibility [57]. In Figure 14b, it is apparent that the large number of fibrils on the cell walls creates new bonds and increases the area of contact.

Bonding between fibers consists of the strength of a single fiber and interfiber bonds $[57,58]$. The TI and BI depend on the strength of interfiber bonds, while TeI depends on the strength of single fiber [56-59]. It is evident from the analysis that the TI and BI increase with the increment of the beating revolution, as in [45]. It is because the beating process enhances the interfiber bonding through increment of the fiber flexibility. On the other hand, the TeI, which is a function of strength of 
single fiber, decreases with the increase in beating revolution. Beating results in shorter fiber length, which causes a decrement of the tear strength.

It is shown that PVA could affect the physio-mechanical performances of the Kenaf paper, as shown in Table 2. It is shown that the apparent density decreases by $19.44 \%$ as $12 \%$ of PVA is introduced. The thickness, TI, and BI increase by $7.09 \%, 1.89 \%$, and $14.54 \%$ with $12 \%$ addition of PVA. The introduction of PVA to the pulp induces new molecular linkage with the fiber cell walls, which increases the fibrilar bridges development on the fiber cell walls, as seen in Figure 16b. As TI and BI parameters are directly proportional to interfiber bonding, therefore the increment of the fibrilar bridges suggest that bonding in between fibers increases, resulting in an improvement of the mechanical strength of the paper. However, PVA does not affect the tear strength of the paper as the tear strength of the paper is related to the strength of the fiber itself. It is interesting to observe the AC breakdown voltage and strength of the Kenaf paper decrease with the increment of the beating revolution. It is anticipated that the decrement of the pore volumes due to the beating leads to the high probability of the breakdown to occur in the Kenaf fibers instead mainly through the discharge channels in pores that are filled with the MO [60]. On other hand, the AC breakdown voltages of Kenaf paper for two and three layers slightly increase as the weight percentage concentration of PVA increases from $3 \%$ to $6 \%$. It is known that the electrical and physiochemical/mechanical strength of solid insulation could be improved through the introduction of enhancement materials $[60,61]$. In the current study, PVA is found to be one of the enhancement substances that can be used to further improve the AC breakdown properties of the Kenaf paper. Nevertheless, further study is required to seek further understanding on the detail mechanisms of breakdown for Kenaf paper under beating and PVA enhancement.

Table 2. Physio-mechanical properties of Kenaf paper without and with PVA.

\begin{tabular}{ccc}
\hline Property & Without PVA & With 12\% of PVA \\
\hline Apparent density $\left(\mathrm{g} / \mathrm{cm}^{3}\right)$ & 0.648 & 0.522 \\
\hline Thickness $(\mu \mathrm{m})$ & 92.99 & 99.59 \\
\hline Tensile index $(\mathrm{Nm} / \mathrm{g})$ & 72.72 & 74.1 \\
\hline Burst index $\left(\mathrm{kPa} \cdot \mathrm{m}^{2} / \mathrm{g}\right)$ & 4.47 & 5.12 \\
\hline Tear index $\left(\mathrm{mN} \cdot \mathrm{m}^{2} / \mathrm{g}\right)$ & 7.49 & 6.67 \\
\hline
\end{tabular}

\section{Conclusions}

The beating process increases the flexibility of the fiber, bonding and leads to denser fiber for the Kenaf paper. Subsequently, this process will lead to the improvement of the physio-mechanical properties. With the introduction of PVA, the TI and BI could increase by $1.89 \%$ and $14.54 \%$, while the TeI decreases by $10.94 \%$. On the other hand, the thickness increases to $7.09 \%$ and density decreases to $19.44 \%$ with the introduction of PVA. The AC breakdown voltage for multiple layers of MO impregnated Kenaf paper decreases as the beating increases. On the other hand, the AC breakdown voltage of MO impregnated Kenaf paper for two and three layers increases as the weight percentage concentration of PVA increases. Further analysis shows that the AC breakdown strength of Kenaf paper is comparable with Kraft paper. The TI of Kenaf insulation paper with PVA is $1.89 \%$ higher than without PVA, but $34.42 \%$ lower than the Kraft paper. It is concluded that PVA could further improve a few of the physio-mechanical and electrical properties of Kenaf paper. However, other enhancement materials could be introduced to Kenaf paper in order to ensure its viability as one of the insulation materials in transformers.

Author Contributions: The research study was successfully completed with contributions from M.U., N.A., R.H. and J.J. The main research idea, experimental works, and manuscript preparation were contributed by M.U. N.A. contributed to the manuscript preparation and the research idea. R.H. assisted with the technical procedure of 
experimental work and finalizing the manuscript. J.J. provided several suggestions on data analysis and finalizing the manuscript. All authors have read and agreed to the published version of the manuscript.

Funding: The research was funded by PUTRA IPS (GP-IPS/2016/9503000) and the Ministry of Higher Education Malaysia FRGS scheme FRGS/1/2019/TK07/UPM/02/3 (03-01-19-2071FR).

Acknowledgments: The authors would wish to express sincere gratitude to pulp and paper laboratory, Forest Research Institute Malaysia (FRIM) for research equipment and support.

Conflicts of Interest: The authors declare no conflict of interest.

\section{References}

1. Liao, R.; Liang, S.; Sun, C.; Yang, L.; Sun, H. A comparative study of thermal aging of transformer insulation paper impregnated in natural ester and in mineral oil. Eur. Trans. Electr. Power 2009, 20, 454-459. [CrossRef]

2. Jeszenszky, S. History of transformers. Power engineering review. IEEE Power Engr. Review 1996, 16, 9-12. [CrossRef]

3. Arsãne, M.-A.; Bilba, K.; Junior, H.S.; Ghavami, K. Treatments of non-wood plant fibres used as reinforcement in composite materials. Mater. Res. 2013, 16, 903-923. [CrossRef]

4. Ashori, A. Nonwood fibers-A potential source of raw material in papermaking. Polym. Technol. Eng. 2006, 45, 1133-1136. [CrossRef]

5. Clark, T.F.; Nieschlag, H.J.; Wolf, I.A. A search for new fibre crops, Part V. Pulping studies on Kenaf. TAPPI J. 1962, 45, 780-786.

6. Khristova, P. Soda-AQ pulp blends from kenaf and sunflower stalks. Bioresour. Technol. 1998, 66, 99-103. [CrossRef]

7. Akgul, M.; Tozluo, A. A comparison of soda and soda-AQ pulps from cotton stalk. Afr. J. Biotechnol. 2009, 8, 6127-6133.

8. Prevost, T.A.; Oommen, T.V. Cellulose insulation in oil-filled power transformers: Part I-History and development. IEEE Electr. Insul. Mag. 2006, 22, 28-35. [CrossRef]

9. Madsen, B.; Gamstedt, E.K. Wood versus plant fibers: Similarities and differences in composite applications. Adv. Mater. Sci. Eng. 2013, 2013, 1-14. [CrossRef]

10. Hurter, R.W. Nonwood plant fiber characteristics. Agric. Residues. 1997, 1, 1-4.

11. Saha, T.K.; Darveniza, M.; Yao, Z.; Hill, D.; Yeung, G. Investigating the effects of oxidation and thermal degradation on electrical and chemical properties of power transformers insulation. IEEE Trans. Power Deliv. 1999, 14, 1359-1367. [CrossRef]

12. Shroff, D.; Stannett, A. A review of paper aging in power transformers. IEEE Proc. C Gener. Transm. Distrib. 1985, 132, 312-319. [CrossRef]

13. Schaible, M. Electrical insulating papers-An overview. IEEE Electr. Insul. Mag. 1987, 3, 8-12. [CrossRef]

14. Sheppard, H. A century of progress in electrical insulation 1886-1986. IEEE Electr. Insul. Mag. 1986, 2, 20-30. [CrossRef]

15. Kaldor, A.F.; Karlgren, C.; Verwest, H. Kenaf, a fast growing fibre source for papermaking. TAPPI J. 1990, 72 , 205-209.

16. Edeerozey, A.M.; Akil, H.M.; Azhar, A.; Ariffin, M.Z. Chemical modification of kenaf fibers. Mater. Lett. 2007, 61, 2023-2025. [CrossRef]

17. Mazuki, A.A.M.; Akil, H.M.; Safiee, S.; Ishak, Z.A.M.; Abu Bakar, A. Degradation of dynamic mechanical properties of pultruded kenaf fiber reinforced composites after immersion in various solutions. Compos. Part. B Eng. 2011, 42, 71-76. [CrossRef]

18. Cho, N. Hanji manufacturing from bast fibers of Kenaf, Hibiscus cannabinus. J. Korea TAPPI. 2008, 40, 1-9.

19. Halis, R. Optimization of Kraft and BioKraft pulping for Kenaf V36. Ph.D. Thesis, Universiti Putra Malaysia, Serdang, Selangor, Malaysia, 2011.

20. Afra, E.; Yousefi, H.; Hadilam, M.M.; Nishino, T. Comparative effect of mechanical beating and nanofibrillation of cellulose on paper properties made from bagasse and softwood pulps. Carbohydr. Polym. 2013, 97, 725-730. [CrossRef]

21. Hernandez, H.R.; Greif, D.S. Process for the Production of Paper Containing Starch Fibers and the Paper Produced Thereby. U.S. Patent 4,243,480, 6 January 1981.

22. Biermann, C.J. Handbook of Pulping and Papermaking; Elsevier: Amsterdam, The Netherlands, 1996. 
23. Yousif, B.F.; Shalwan, A.; Chin, C.W.; Ming, K.C. Flexural properties of treated and untreated kenaf/epoxy composites. Mater. Des. 2012, 40, 378-385. [CrossRef]

24. Masrol, S.; Ibrahim, M.H.I.; Adnan, S.; Shah, M.S.S.A.; Main, N.M.; Esa, M.; Othman, M. Effect of beating process to soda anthraquinone pulp of oil palm male flower spikes fibre. Appl. Mech. Mater. 2015, 773, 158-162. [CrossRef]

25. Bajpai, P. Brief description of the pulp and papermaking process. In Biotechnology for Pulp and Paper Processing; Springer Science and Business Media LLC: Berlin, Germany, 2018; pp. 9-26.

26. Gill, R.I.S. Developments in retention aid technology. Paper Technol. 1991, 6-11.

27. Solikha, D.F. Analysis qualitative addition of additives substance to paper making process in paper machine. J. Green Sci. Technol. 2020, 4.

28. González, I.; Boufi, S.; Pèlach, M.A.; Alcalà, M.; Vilaseca, F.; Mutjé, P. Nanofibrillated cellulose as paper additive in eucalyptus pulps. Bioresources 2012, 7, 5167-5180. [CrossRef]

29. Abdulkhani, A.; Marvast, E.H.; Ashori, A.; Hamzeh, Y.; Karimi, A.N. Preparation of cellulose/polyvinyl alcohol biocomposite films using 1-n-butyl-3-methylimidazolium chloride. Int. J. Biol. Macromol. 2013, 62, 379-386. [CrossRef] [PubMed]

30. Xu, R.; Wang, C.; Wu, S.; Chen, K. Effects of the polymeric additives on the stickies formation in recycled fibers based papermaking process. Nord. Pulp Paper Res. J. 2017, 32, 647-655. [CrossRef]

31. Hamzeh, Y.; Sabbaghi, S.; Ashori, A.; Abdulkhani, A.; Soltani, F. Improving wet and dry strength properties of recycled old corrugated carton (OCC) pulp using various polymers. Carbohydr. Polym. 2013, 94, 577-583. [CrossRef] [PubMed]

32. Rojas, O.J.; Neuman, R.D. Adsorption of polysaccharide wet-end additives in papermaking systems. Colloids Surf. A Physicochem. Eng. Asp. 1999, 155, 419-432. [CrossRef]

33. Umair, M.; Azis, N.; Halis, R.; Jasni, J. Investigation on the Effect of Beating on the Physical and Mechanical Properties of Untreated Kenaf Based Insulation Paper. In Proceedings of the 2018 IEEE 5th International Conference on Smart Instrumentation, Measurement and Application (ICSIMA), Songkla, Thailand, 28-30 November 2018; Institute of Electrical and Electronics Engineers (IEEE): New York, NY, USA, 2018; pp. 1-6.

34. Freeness of pulp. In TAPPI T 227; The Technical Association of Pulp and Paper Industry: Atlanta, GA, USA, 1999.

35. Fiber length of pulp by classification. In TAPPI T 233; The Technical Association of Pulp and Paper Industry: Atlanta, GA, USA, 1998.

36. Laboratory beating of pulp. In TAPPI T 248; The Technical Association of Pulp and Paper Industry: Atlanta, GA, USA, 2001.

37. Forming Handsheets for Physical Tests of Pulp. In TAPPI T 205; The Technical Association of Pulp and Paper Industry: Atlanta, GA, USA, 2015.

38. Insulating liquids-Determination of the breakdown voltage at power frequency-Test method. In IEC 60156; International Electrotechnical Commission: Geneva, Switzerland, 2018.

39. Thickness of paper and paperboard. In TAPPI T 411; The Technical Association of Pulp and Paper Industry: Atlanta, GA, USA, 1997.

40. Grammage of paper and paperboard. In TAPPI T 410; The Technical Association of Pulp and Paper Industry: Atlanta, GA, USA, 2013.

41. Tensile properties of paper and paperboard. In TAPPI T 494; The Technical Association of Pulp and Paper Industry: Atlanta, GA, USA, 2006.

42. Bursting strength of paper. In TAPPI T 403; The Technical Association of Pulp and Paper Industry: Atlanta, GA, USA, 1997.

43. Internal Tearing Resistance of Paper. In TAPPI T414; The Technical Association of Pulp and Paper Industry: Atlanta, GA, USA, 2012.

44. Khakifirooz, A.; Kiaei, M.; Sadegh, A.N.; Samariha, A. Studies on chemical and morphological characterics of Iranian cultuvated Kenaf (Hibiscus cannabinus L.) A potential source of fibrous raw material for paper industry in Iran. Res. Crop. 2012, 13, 715-720.

45. Umair, M.; Azis, N.; Halis, R.; Jasni, J. Examination on the physical properties of untreated kenaf insulation paper at different beating degrees. Indones. J. Electr. Eng. Comput. Sci. 2020, 17, 759-766. [CrossRef] 
46. Wang, Z.; Pang, L.; Wang, T.; Yang, H.; Zhang, Q.; Li, J. Breakdown characteristics of oil-paper insulation under lightning impulse waveforms with oscillations. IEEE Trans. Dielectr. Electr. Insul. 2015, 22, 2620-2627. [CrossRef]

47. Grzybowski, S. DC and AC breakdown voltage behavior of high voltage multi-layer encapsulated coils. In Proceedings of the 11th International Symposium on High-Voltage Engineering (ISH 99), London, UK, 23-27 August 1999; Volume 4, p. 308. [CrossRef]

48. Liu, Y.X. Water accumulation in oil-paper insulation transformer and its influence to life time. Transformer 2004, 41, 8-13.

49. Joshi, A.; Kumar, S. Variation of dielectric strength of a insulation paper with thermal aging. NDT E Int. 2005, 38, 459-461. [CrossRef]

50. Werdouschegg, F.M.K. Dry Strength Additives; Reynolds, W.F., Ed.; Tappi Press: Atlanta, GA, USA, 1980; pp. 67-93.

51. Campbell, W.B. The mechanism of bonding. Tappi J. 1959, 42, 999-1001.

52. Hubbe, M.A. Bonding between cellulosic fibers in the absence and presence of dry strength agents-A review. BioResources 2006, 1, 281-318. [CrossRef]

53. Kohman, G.T. Cellulose as an insulating material. Ind. Eng. Chem. 1939, 31, 807-817. [CrossRef]

54. Wathen, R. Studies on fiber strength and its effect on paper properties. In KCL Communications 11; KCL: Espoo, Finland, 2006; p. 98.

55. Van den Akker, J.A.; Jentzen, C.A.; Spiegelberg, H.L. Effect on individual fibers of drying under tension. In Consolidation of the Paper Web; Transactions of the 3rd Fundamental Research Symposium: Cambridge, UK, 1965; Volume 1, pp. 477-506. Available online: https://bioresources.cnr.ncsu.edu/resources/effects-onindividual-fibres-of-drying-under-tension/ (accessed on 3 July 2020).

56. Nanko, H.; Ohsawa, J. Structure of fiber bond formation. In Fundamentals of Papermaking; Baker, C.F., Punton, V.W., Eds.; Mechanical Engineering Publications Limited: London, UK, 1989; Volume 2, pp. 786-830. Available online: https://bioresources.cnr.ncsu.edu/resources/mechanisms-of-\%EF\%AC\%81bre-bond-formation/ (accessed on 3 July 2020).

57. Uesaka, T.; Retulainen, E.; Paavilainen, L.; Mark, R.E.; Keller, D.S. Determination of fiber-fiber bond properties. In Handbook of Physical Testing of Paper; Informa UK Limited: London, UK, 2001; pp. 897-924.

58. Vainio, A.; Kangas, J.; Paulapuro, H. The role of TMP fines in interfiber bonding and fiber segment activation. J. Pulp Pap. Sci. 2007, 33, 29-34.

59. Wahlström, T. Influence of Shrinkage and Stretch During Drying on Paper Properties. Licentiate Thesis, Royal Institute of Technology, Department of Pulp and Paper Chemistry and Technology, Division of Paper Technology, Stockholm, Sweden, 1999.

60. Giese, K. The effects of cellulose insulation quality on electrical intrinsic strength. IEEE Electr. Insul. Mag. 1994, 10, 38-42. [CrossRef]

61. Nazir, M.T.; Phung, B.T.; Li, S. Erosion resistance of micro-AlN and nano-SiO ${ }_{2}$ hybrid filled silicone rubber composites. In Proceedings of the 2017 International Symposium on Electrical Insulating Materials (ISEIM), Toyohashi, Japan, 11-15 September 2017; pp. 370-373. [CrossRef]

Publisher's Note: MDPI stays neutral with regard to jurisdictional claims in published maps and institutional affiliations.

(C) 2020 by the authors. Licensee MDPI, Basel, Switzerland. This article is an open access article distributed under the terms and conditions of the Creative Commons Attribution (CC BY) license (http://creativecommons.org/licenses/by/4.0/). 